\title{
Det danske Sprogs Stilling i Mellemslesvig i 1946
}

Af Christian Stenz.

Der er Grund til at antage, at de kommende Aar vil opleve afgørende Ændringer i Sprogforholdene i Sydslesvig, navnlig i det endnu overvejende dansktalende Omraade i Mellemslesvig. For det første vil temmelig givet det store Fremmedelements Tilstedeværelse influere paa det daglige Talesprog, og for det andet foreligger den Mulighed, at Oprettelsen af de mange danske Skoler og hele det Kulturarbejde, der nu udføres fra dansk Side, inden længe vil medføre Virkninger paa Talesproget. Hvilken af de to hver for sig i dette Forhold betydende Faktorer, Flygtningene eller de danske Skoler, der faar den største Indflydelse, vil afhænge af de statspolitiske Forudsætninger, som endnu er ukendte. Men for at kunne danne sig et Billede af de sidste 10-15 Aars sproglige Udvikling i statistisk Belysning, er det nødvendigt, at en Undersøgelse finder Sted netop nu.

En fremtrædende Sydslesviger, der kender sin Landsdel ud og ind, vilde for nylig hævde Umuligheden af overhovedet at lave Sprogstatistik. Han brugte bl. a. dette Eksempel som Argument: Naar en Far taler Tysk til een Søn, Dansk til en anden, saa kan man hverken kalde denne Familie dansk- eller tysktalende. Det er naturligvis rigtigt, og de ældre Undersøgelser opererer derfor med meget store Grupper, som benævnes blandingssprogede, saaledes Flensborg Dommeren Adlers, der udkom 1890. H. V. Clausen paaviste senere (i Sønderjydske Aarbøger 1892-93), at Adlers blandingssprogede i Virkeligheden var dansksprogede.

Fremstillingen af de sproglige Forhold er dog ikke slet saa enkel. Forfatteren til den nyeste Undersøgelse af Sprogforhol- 
dene i Grænseomraadet mellem Dansk og Tysk, Poul Selk, anvender i sit Arbejde, „Die sprachlichen Verhältnisse im deutschdänischen Sprachgebiet südlich der Grenze“ (Flensborg 1937), en Fremgangsmaade, der ikke indskrænker sig til at fastslaa Paastande om saa og saa mange Procent henholdsvis tysk- og dansktalende $i$ et Sogn. Han undgaar en Gentagelse af Adlers Fejlgreb ved at foretage en Opdeling i Grupper, der angiver henholdsvis \#gtefællers indbyrdes Talesprog, deres Talesprog med Børn og Antallet af Familier med kun eet Sprog. Paa forskellige Tavler A, B, og C stilles følgende Spørgsmaal: A: Hvad taler ÆEgtefællerne indbyrdes?, B: Hvad taler Forældrene med deres Børn?, og C: I hvor mange Familier tales der kun Dansk, Højtysk, Plattysk eller Frisisk? I en Tavle D spørges desuden om Skolebørnenes Forældres indbyrdes Talesprog og disses Talesprog med Børnene.

Herigennem underseges ikke et vist Antal Personer som saadan, men Familier og disse igen $i$ to eller tre Generationer. For at undgaa det misvisende Billede, som det giver at medregne tilvandrede, herunder Tolder- og andre Tjenestemandsfamilier, har Selk for hver Tavle en Rubrik, der kun behandler de fra gammel Tid hjemmehørende (,alteingesessene“) Farniliers Talesprog.

Den af Selk anvendte Metode fritager for den Stivhed, der kendetegnede forrige Undersøgelser. At han samtidig er gaaet til Værket med det Formaal at give en redelig og sanddru Fremstilling er hævet over enhver Tvivl. Redaktør Tage Jessen, der er særdeles kyndig paa dette Omraade, betegner Selks Arbejde som „en sikkert $90 \%$ rigtig Sprogstatistik“. Og nærmere kan man temmelig givet ikke komme Sandheden. En Kontrolprøve fra dansk Side i 1938 bekræfter Selks \&Edruelighed. $\left.{ }^{*}\right)$

*) Karl N. Bock: Mellemslesvigs Sprogforhold i Fr. v. Jessen: Haandbog $i$ det slesvigske Sporgsmaal. 
Det er med fuld Ret, der gives en Margin paa $10 \%$. Foruden det før omtalte Eksempel paa, hvor vanskeligt det kan være at bedømme en Families sproglige Forhold rigtigt, kunde der nævnes utallige andre. Ofte taler en af ÆEgtefællerne Dansk med Børnene, den anden Tysk, selv om de maaske taler Dansk indbyrdes - og uden at der foreligger nationale Motiver for nogen af Parterne. Endnu hyppigere forekommer det, at Forældrene taler Dansk med de større Børn, Tysk med de mindre. (Jeg har kun konstateret et enkelt Eksempel - i Medelby Sogn - paa det modsatte).

Der bliver saaledes Tale om en Mængde Tvivlstilfælde, ikke i den Forstand, at man er afskaaret fra at faa Oplysninger om de enkelte Familiemedlemmers Talesprog, men Tvivl om, i hvilken Rubrik, blandt dansk-, tysk- eller plattysktalende, man skal anbringe dem. Det skulde være muligt at faa nogenlunde paalidelige Meddelelser om de enke]te Familiemedlemmers Sprog.*) Dersom i visse særligt tvivsomme Tilfælde Hjemmelsmændene giver forskellige Oplysninger, kan man blive tvunget til at anvende en skønsmæssig eller en Sandsynlighedsberegning. Her kan der være Grund til at paaskønne den $10 \mathrm{pCt}$. Margin for Fejltagelser. Jeg vil dog tro, at eventuelle Fejlkeregninger i henholdsvis dansk og tysk Favør nogenlunde ophæver hinandens Virkninger. Jeg vil ogsaa antage, at man for Tavle A. kan sætte Rigtighedsprocenten højere end til 90, mens den muligvis for Tavle B. skal sættes noget lavere. Det samme gælder uden Tvivl for Tavle C. For selv om vi regner Familier, hvor Forældre taler det samme Sprog indbyrdes og med Børnene, for rensprogede, saa er det langtfra udelukket, at man ind imellem kan benytte et andet Sprog. (Tavle D. undlader jeg helt $\mathrm{i}$ denne Undersøgelse).

*) Adler byggede sine Undersøgelser paa de undersøgte Personers egne Vidneudsagn. Erfaringen viser, at Oplysningerne bedst kan gives af fremmede. Det skal $i$ denne Forbindelse anføres, at jeg alene for Medelby Sogn har haft 21 forskellige Meddelere. 


\section{Sprogskiftet.}

Om Aarsagerne til dette er der talt og skrevet tilstrækkeligt. Her skal kun bemærkes, at Sprogskiftet i Mellemslesvig er foregaaet en Del anderledes end i Angel, hvor for c. 100 Aar siden Overgangen fra Dansk til Plattysk foregik i Iltempo. I Mellemslesvig foregaar Skiftet meget langsomt, og det bevæger sig almindeligvis fra Dansk over det højtyske Skole- og Kirkesprog til Plattysk. Af Skemaerne vil det fremgaa, hvad baade Selk og Bock har gjort opmærksom paa, at jo længere Sprogskiftet er trængt igennem, desto større Udbredelse faar Plattysk paa Bekostning af Højtysk. Her maa navnlig henvises til Medelby og Læk Sogne.

Som tidligere antydet ligger der sjældent bevidst nationale Motiver bag ved Sprogskiftet. De Voksne har svært ved at bryde med den gamle Sædvane, som Benyttelsen af det danske Sprog betyder, men det er ogsaa blevet Tradition, at der med Børnene skal tales Tysk. Selv dansktalende Forældre og Bedsteforældre vedbliver at tale Tysk med Børn, som gaar i dansk Skole. Et Eksempel kan illustrere Forholdet: En dansktalende Kone var hos en dansk Lærerfamilie. Al Samtale blev naturligvis ført paa Dansk, men da Familiens yngste, et Barn paa et halvt Aar, blev forevist; begyndte Konen straks at underholde sig med den lille paa Tysk.

Et andet Eksempel: En dansktalende Kone har taget sine to Børnebørn til sig. Børnene taler Dansk indbyrdes og med de fleste Kammerater, Bedstemoderen taler ogsaa Dansk med alle andre, men til Børnene taler hun kun Tysk og faar Svar paa Tysk. Vanens - eller Traditionens - Magt er stor.

For hvert Aar, der gaar, spores en lille Tilbagegang i Antallet af dansktalende Familier. Enten man kalder det naturligt eller unaturligt, saa har denne Udvikling - indtil nu været uafvendelig. Den danske Tilbagegang er som sagt foregaaet langsomt og gradvist, men den er ikke til at komme 
udenom. Denne Undersøgelse skulde paavise den kontinuelle eller - om man vil - naturlige Udvikling $i$ de sidste 10-15 Aar, og det er som tidligere nævnt i Sagens Interesse paakrævet, at den foretages, inden Indflydelsen af Flygtningene eller de danske Skoler bliver mærkbar.

Det her foreliggende Arbejde er langtfra saa omfattende som Selks. Det bygger fuldtud paa de af denne givne Retningslinier og kan saaledes kun betragtes som en Videreførelse af hans Arbejde - samtidig med, at det til en vis Grad kan kontrollere dette. Der er Opgivelser fra ialt 8 Sogne i Sydtønder Amt, men kun i tre af disse - Medelby, Aventoft og Nykirke Sogne - omfatter Undersøgelsen hele Sognet. Naturligvis er Flygtningene udeladt af Beregningerne, ligesom der heller ikke er taget Hensyn til, dersom Familier som Følge af den nyeste nationale Udvikling skulde have skiftet Talesprog. Det er iøvrigt mit Indtryk, at saadanne Skifter indtil nu (Januar 1947) kun har fundet Sted i meget ringe Udstrækning.

\section{Medelby Sogn.}

Medelby Sogn er det østligste Omraade i Sydtønder Amt. Det er baade i Henseende til Udstrækning og til Folketal det storste af de undersøgte Sogne.

Bortset fra Læk Sogn er Medelby Sogn det, som i Dag er stærkest i Farezonen. I 1890 opgav Adler, at der var 78,4\% dansktalende. H. V. Clausen fik to Aar efter 88,6 \%. Selk oplyser, at $46,8 \%$ af $Æ g$ tefællerne taler Dansk indbyrdes, mens efter mine Beregninger dette Procenttal i 1946 skulde være dalet til 38,9 .

Selks Tal viser, at der er store Forskelligheder inden for Sognet. Det ses, at Forskellene ikke er saa iøjnefaldende i 1946, at de mest tysktalende Distrikter har den forholdsvis mindste Tilbagegang, hvilket kunde tyde paa, at der er indtraadt en vis Stilstand i Sprogskiftet her, hv̀or en fast Blok af Familier kun- 


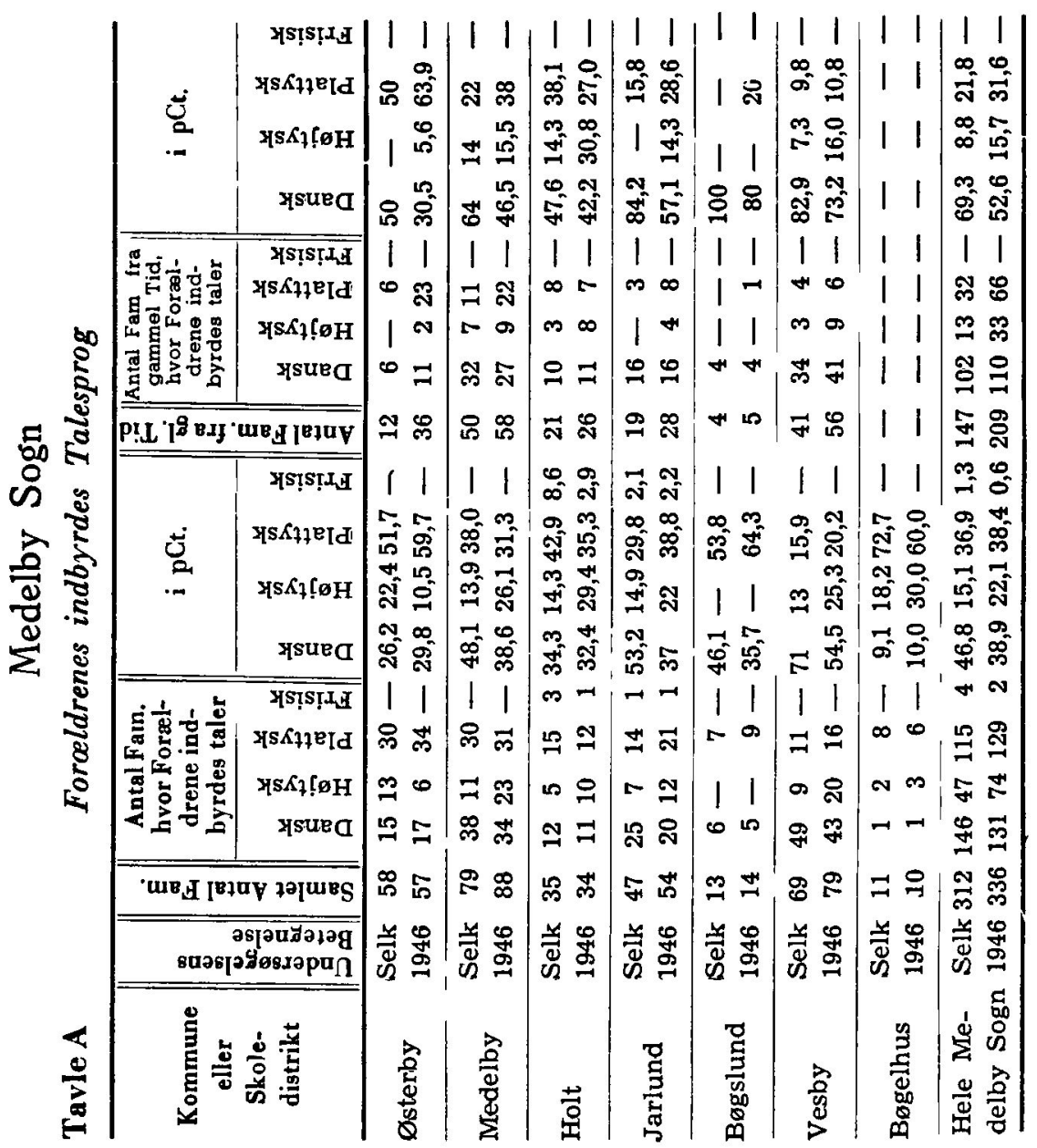

de synes at holde fast ved det danske Sprog. I den østligste Kommune, Østerby, er der oven i Købet en dansk Fremgang fra 26,2-29,8 $\%$. Bortset fra Nykirke Sogn er dette Tilfælde enestaaende. Nedgangen er størst i Vesby og Jarlund. I Vesby er endnu over Halvdelen af \#gteparrene dansktalende, men i Jarlund, som er blevet kaldt „Det lille Danmark" og hvor der ved Afstemningen i 1920 var dansk Flertal, er de dansktalende EEgtepar kommet i Mindretal (fra 53,2-37 of). 


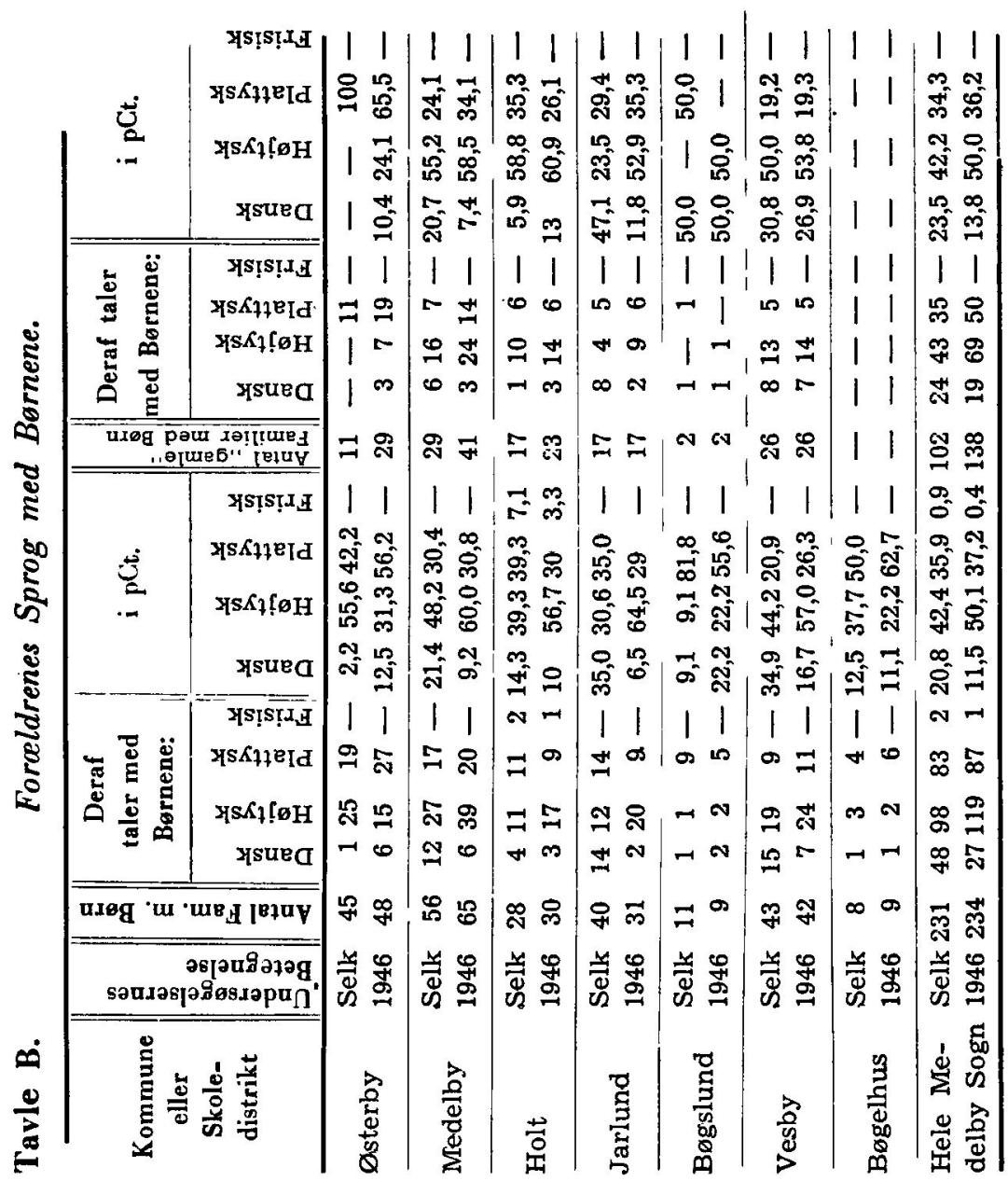

Vesby og Jarlund er begge Grænsedistrikter, hvorfor der bor en Del Toldfunktionærer her. Tages den danske Procent af de fra gammel Tid hjemmehørende, er der endnu dansk Flertal i Jarlund, mens baade Medelby og Østerby har mistet dette Flertal. 


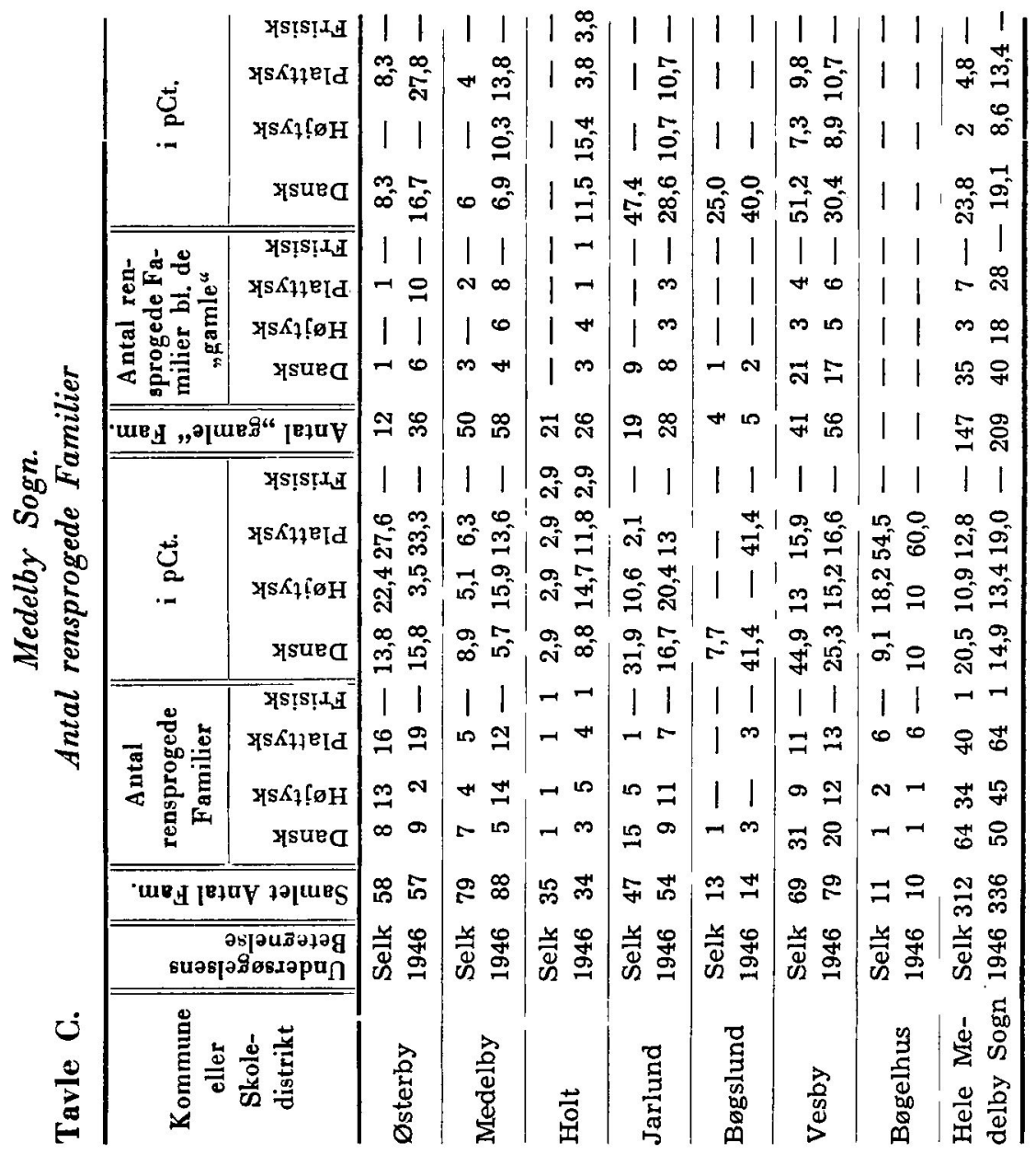

I Holt Kommune*) er der kun sket smaa Endringer. Dette hænger sikkert sammen med, at der her findes mange Udflyttere - de spredte Bebyggelser Holt Mark, Aabro og Horsbæk hører hertil - og Udflyttere er langt mere trofaste over fol Modersmaalet end Landsbysamfundene.

*) Hvert Omraade betegner enten et Skoledistrikt eller en Kommune. Efter den tyske Kommunalordning er Kommunerne ofte ganske smaa Samfund. (I Bøgslund Kommune findes der f. Eks. ialt kun 33 indfødte Vælgere). Der er 6 Kommuner i Medelby Sogn. 
Tavle B. giver et ganske andet Billede end Tavle A. At der to Steder, i Østerby og Bøgslund, noteres en dansk Fremgang, kan ikke borttage Indtrykket af en ellers meget stor Tilbagegang for det danske Sprog. I den lille Bøgslund Kommune kan Fremgangen fra 9,1 til 22,2\% forklares derved, at blot een Familie $\in \mathrm{r}$ tilflyttet fra Agtrup i den mellemliggende Tid. I Østerby $\epsilon \mathrm{r}$ der nu 6 Familier mod før 1, der taler Dansk med Børnene, men der er $\mathrm{i}$ den forløbne Tid dannet nye Hjem blandt de dansksindede paa Østerby Mark - og saa har vi jo vor Margin for Fejltagelser.

I Jarlund er Nedgangen næsten ufattelig stor, fra 35 til $6,5 \%$. Og det samme Forhold er til Stede blandt de "gamle“ Familier, modsat Vesby, hvor Tilbagegangen her kun er ringe. Blandt alle Familier i Vesby er Procenten godt halveret.

Til Vesby hører den lille Landsby Vesbydam. Denne er den Dag i Dag rent dansktalende, og selv om man ogsaa her angiver at tale Tysk med Børnene, saa betyder det kun lidt, da alle Børn herfra kan tale Dansk. Jeg har hørt Børn fra Øvre-Schlesien efter et halvt Aars Ophold i Vesbydam tale flydende Dansk. En tidligere tysk Lærer i Vesby fortæller mig, at endnu i 1942 talte alle Børn fra Vesbydam Dansk paa Skolevejen.

En ung Mand paa 23 Aar fortæller, at i hans Skoletid hørte man næsten kun Dansk paa Skolepladsen i Vesby. I 1946 talte Børnene i den danske Skole Tysk paa den samme Skoleplads. Man bliver gennem disse Oplysninger tilbøjelig til at godkende de Forandringer, som Tavle B. giver Udtryk for, som værende rigtige.

I Holt og Bøgelhus er der kun smaa Ændringer at bemærke. Det sidste Sted er udelukkende et Samfund af tilflyttede Kolonister.

Derimod synes det, som om selve Medelby snart staar over for sidste Fase i Sprogkampen. Antallet af Familier, der taler 
Dansk med Børnene, er mere end halveret, og selv om alle lidt ældre Personer kan tale Dansk, saa er der blandt den voksne Ungdom kun et Mindretal tilbage, der behersker dette Sprog. Mens man paa Gaden i Vesby næsten kun hører Dansk mellem de Voksne - saa bliver dette mere og mere en Sjældenhed i Medelby. I denne Forbindelse er det bemærkelsesværdigt, at Nedgangen for denne Tavles Vedkommende er størst blandt de "gamle" Familier.

Selks 20,8\% paa Tavle B. for hele Sognet, skulde saaledes i 1946 være faldet til 11,5, omtrent til det halve. For de "gamle" er Nedgangen fra $23,5-13,8 \%$.

Tavle C. viser den samme Tendens som de to foregaae:ade. Det er den Tavle, hvor der er størst Spillerum for Fejltagelser. Antallet af de rensprogede Familier i Medelby Sogn udgør 47,3 \%, men deraf kan man ikke slutte bestemt, at der tales Dansk i de ovrige 52,7 \% af Familierne. Mange taler baade Højtysk og Plattysk.

I Vesby er der dansk Tilbagegang, men plattysk- og hojtysktalende er kun gaaet en Ubetydelighed frem. Her er Sprogskiftet altsaa kun i sin Vorden. I Jarlund er Processen skredet langt videre frem. De rent højtysktalendes Antal er fordoblet og de plattysktalendes steget fra 2,1 til $13 \%$, altsaa til over det seksdobbelte. Endnu grellere belyser Rubrikken for de "gamle“ Tilbagegangen.

I Medelby gaar Dansk tilbage og Høj- og Plattysk frem.

Bøgslund er saa lille - det samme gælder Bøgelhus - at et Par enkelte Til- og Fraflytninger kan medføre store procentuale Forskydninger. Derfor kan man gaa let hen over disse.

I Østerby er der som paa de andre Tavler en lille dansk, men en stor plattysk Fremgang. Man kan forudse, at denne By umærkeligt glider ind i det plattysktalende Omraade.

For Medelby Sogn er Stillingen altsaa den, at kun i Vesby taler et Flertal af Ægtefællerne Dansk indbyrdes. Kun naar 
man indskrænker sig til de fra gammel Tid hjemmehørende, kan Jarlund og Bøgslund medregnes i det ovenanførte dansktalende Omraade. Men det danske Sprog er trods alt langt fra at være doende i Sognet, og det er givet, at det benyttes - eller i det mindste kan benyttes - i langt højere Grad end en Statistik kan give Udtryk for.

\section{Ladelund og Bramsted.}

I Ladelund Sogn har det danske Sprog holdt sig langt bedre end i Medelby. Adler angav de dansktalende til $90,3 \%$ og $\mathrm{H}$. V. Clausen til 95,5 \%.

Baade for Ladelund og Bramsted kan der gives 3 forskellige Statistikker, Selks fra 1932, min Kontrolprøve af disse Resultater fra 1938 og den sidste fra 1946.

Som det ses, er der i Ladelund kun sket ubetydelige AEndringer fra 1932 til 1946. Baade for alle Familier og for de "gamle“ alene er Afvigelserne kun 5-6 \%. Derimod er Resultaterne fra 1938 noget gunstigere for det danske Sprog end Selks Opgivelser.

I Bramsted er der for Tavle A.s Vedkommende saa godt som ingen Forskel paa Tallene $i$ de tre Undersøgelser. Der er henholdsvis 59, 60,5 og 59,1\% dansktalende. For de gamle Familier er Forholdet omtrent det samme, 90,9, 86,7 og 90,5 \%. Fremgangen for de "gamle" forklares ved Tilvæksten paa $6 \mathrm{Fa}-$ milier.*)

Tavle B. frembyder betydeligt større Afvigelser. I Ladelund er Procenten af de Familier, der taler Dansk med Børnene for de tre Perioder $74,4,34,1$ og 29,5. Jeg er tilbøjelig til at antage, at Selk har indrømmet de dansktalende under Tavle B. en lidt for høj Plads, ligesom jeg paa den anden Side fristes til at tro, at mine Resultater fra 1938 ikke yder. de dansktalende

*) I Bramsted, men derimod ikke : Ladelund, har jeg haft de samme Hjemmelsmænd som i 1938. 


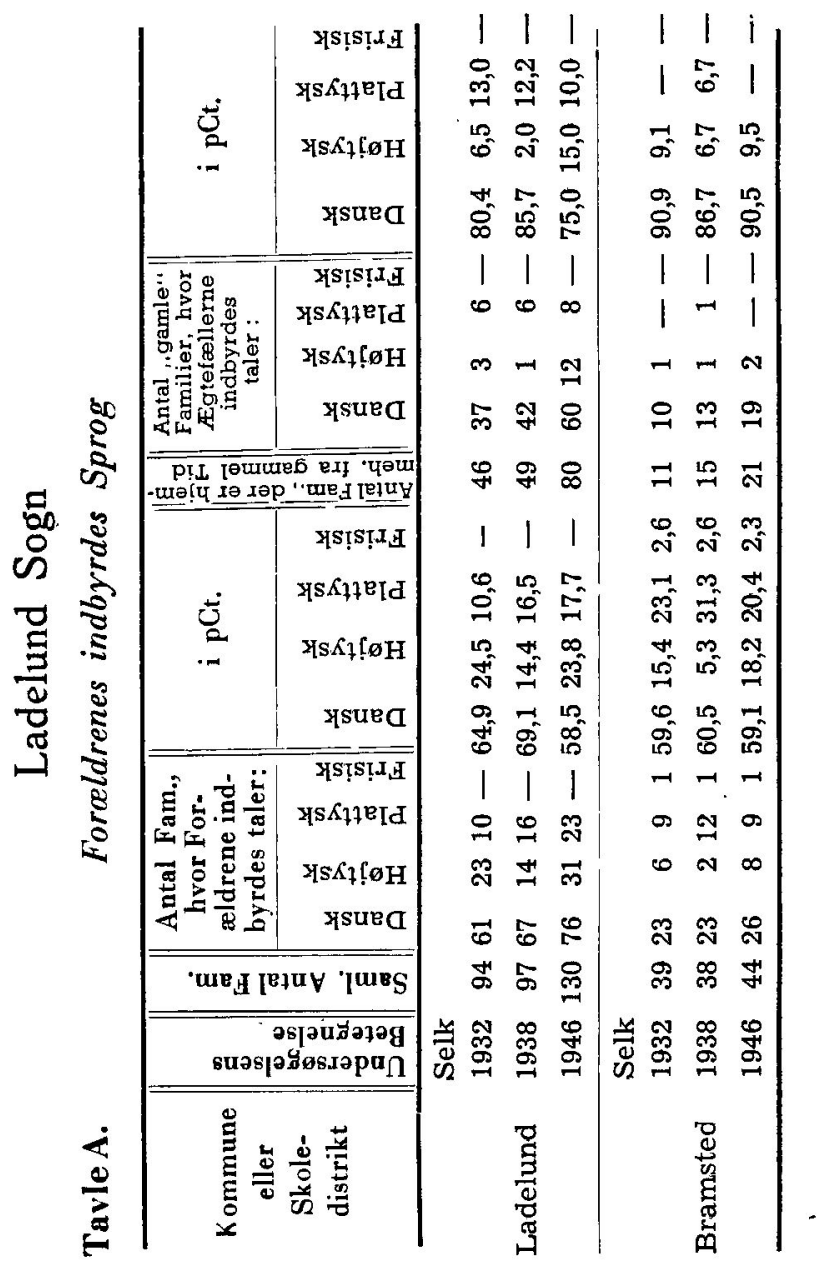

fuld Retfærdighed. I Forhold til Tal fra andre undersøgte Lokaliteter skulde Tilbagegangen fra 74,4 $\%$ i 1932 til 29,5 \% i 1946 ikke synes helt overvældende. Skulde alle tre Resultater være paalidelige - eller saa paalidelige, som de under de givne F'orudsætninger kan blive - saa bliver kun den Mulighed tilbage, at den store Tilbagegang for det danske Sprog er sket allerede mellem 1932 og 1938 og ikke, som man ellers snarest 


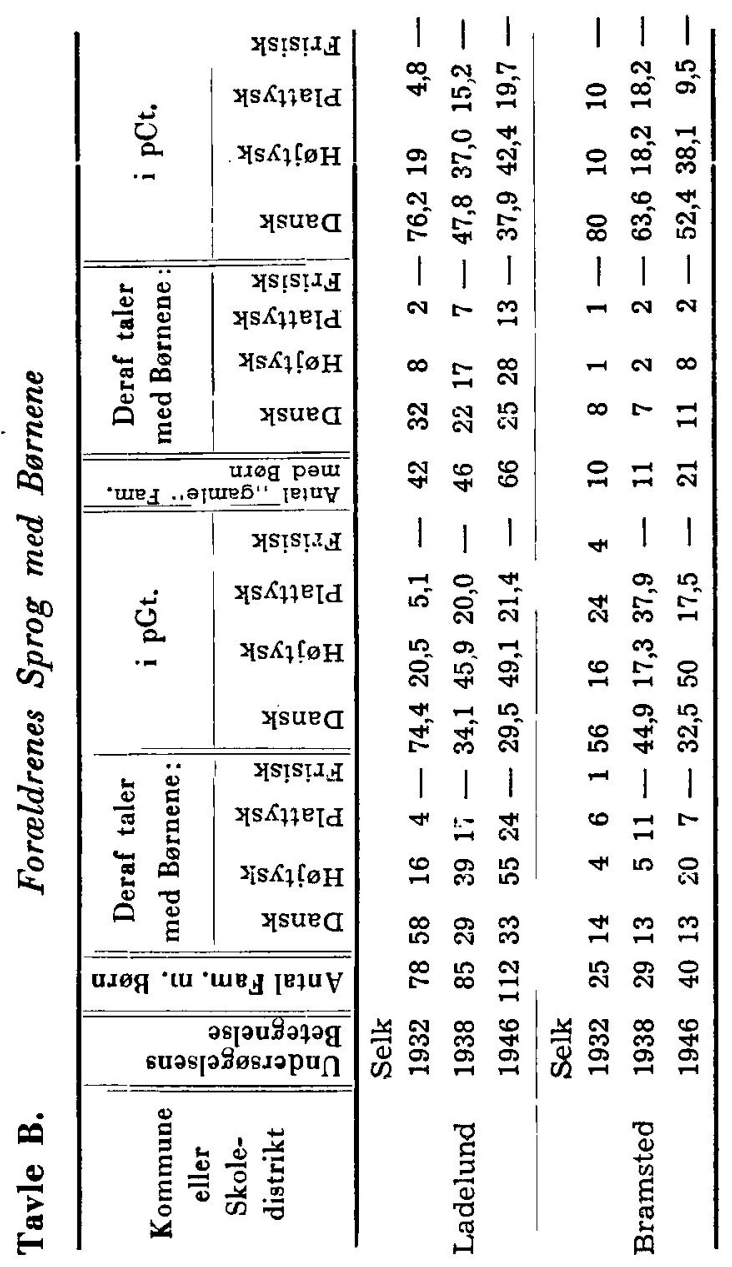

vilde mene, under Krigen. Men om dette kan der kun gisnes. Nogen Opklaring af Problemet kan ikke tænkes.

At det danske Omgangssprog blandt Børnene i Ladelund er levedygtigt nok endnu, viser den Kendsgerning, at Flygtningetørnene her ligesom i Vesbydam lærer at tale Dansk.*)

Lærer Lindstrøm, Ladelund, oplevede i 1937 følgende lille

*) Meddelt af Lærer Dinsen Hansen, Nibøl, tidligere Ladelund. 


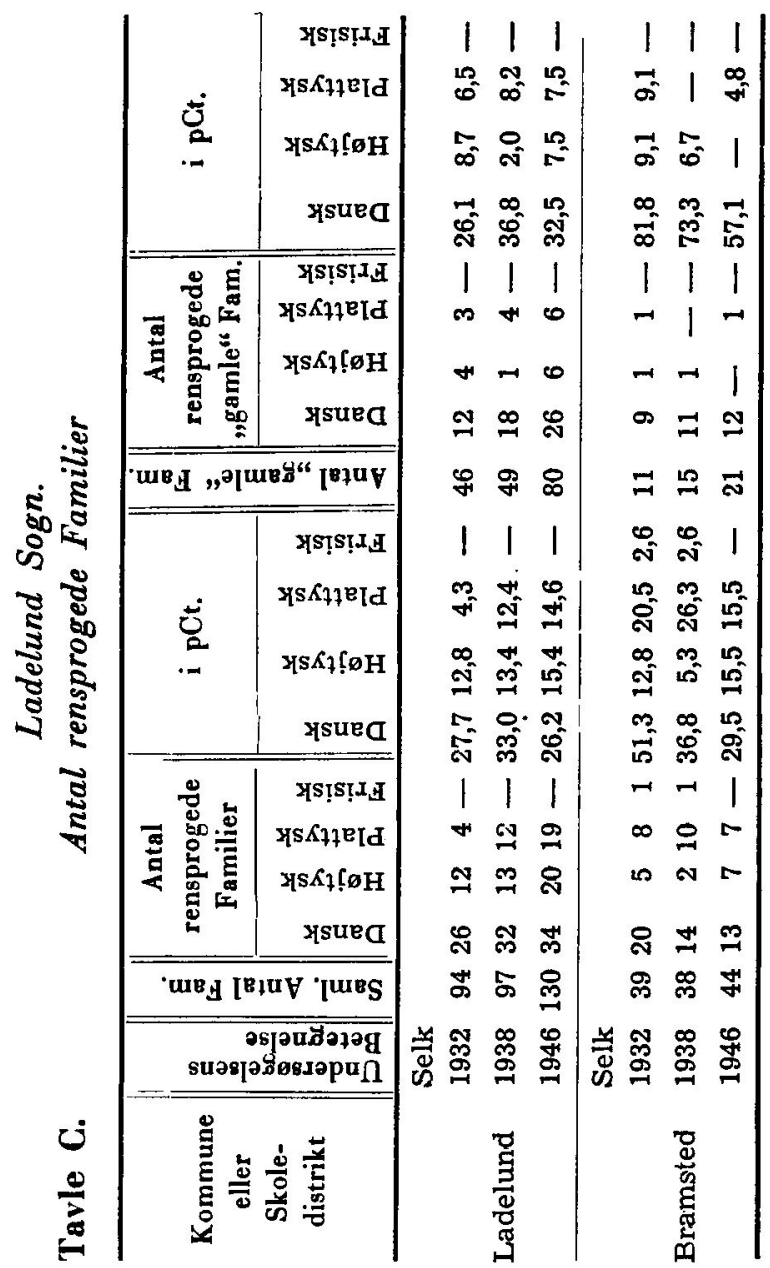

Træk: Gendarmens lille Dreng, der Aaret før var kommet fra Hamburg, hjalp med at drive en Ko, og han udbrød paa godt Sønderjydsk: „Kan du saa gaa, dit Stykke Skidt!“

Baade for Ladelund og Bramsted synes Procenterne for de "gamle" at bekræfte Teorien om, at Tilbagegangen er sket før 1938. Iøvrigt viser Bramsted Kontinuitet i Tilbagegangslinien for det danske Sprog. 
For Ladelund giver Tavle $\mathrm{C}$. omtrent det samme Billede som Tavle A. 27,6, 33,0 og 26,2 or og for de "gamle“ 26,1, 36,8 og 32,5\% i de tre Undersøgelser. Fremgangen for Højtysk er kun ringe, men en Del Familier synes at være gaaet ind $i$ de plattysktalendes Rækker. Blandt de "gamle“ spores dog ingen Fremgang i denne Henseende.

I Bramsted er Nedgangen for Tavle C. storre end i Ladelund. Landsbyen var i 1932 det Distrikt i Ladelund Sogn, hvor Dansk taltes mindst, men det synes trods alt, som om Dansk holder sig helt godt.

I det hele taget viser alle tre Tavler for begge Landsbyer kun smaa Udslag - bortset fra Tavle B. for Ladelund - i Sammenligning med Udviklingen i Medelby Sogn.

\section{Agtrup.}

I Læk Sogn er det kun i den store Landsby Agtrup, at man kan finde et større dansktalende Element. Adler og H. V. Clausen opgav i sin Tid henholdsvis 74,3 og $77 \%$ dansktalende i Ag-

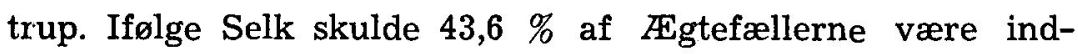
byrdes dansktalende, og dette Tal er nu dalet til $32,9 \%$. Det ses paa Tavle B., at nu kun 8 Familier mod før 25 taler Dansk med Bornene. Den danske Procent er dalet fra 22,7 til 8. Paa Tavle C. er Nedgangen lidt mindre, fra 26-14,6\%.

Paa Skemaerne er ikke medtaget Beregninger over de "gamle" Familiers Talesprog. Selks Resultater saa saaledes ud: $49,2 \%$ dansktalende, $13,8 \%$ højtysktalende, $35,4 \%$ plattysktalende og 1,5 \% frisisktalende. Efter en løselig Udregning skulde Procenterne i Dag se saaledes ud: Dansk: 28,7, Højtysk: 11,9, Plattysk: 58,4 og Frisisk: $1 \%$. (Alt gælder kun Tavle A.). Selv om dette giver et noget gunstigere Billede, saa kan Helhedsindtrykket ikke bortforklares. Dette fortæller, at det danske Sprog i Agtrup langsomt nærmer sig Udslettelsen. Lærer Ryge Petersen, Agtrup danske Skole, der har foretaget Under- 


\section{Agtrup}

Tavle A. Forceldrenes indbyrdes Sprog

\begin{tabular}{|c|c|c|c|c|c|c|c|c|c|}
\hline \multirow{2}{*}{ 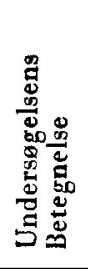 } & \multirow{2}{*}{ 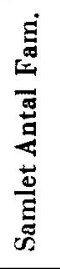 } & \multicolumn{4}{|c|}{$\begin{array}{c}\text { Antal Familier, hvor } \\
\text { Egtefællerne } \\
\text { indbyrdes taler: }\end{array}$} & \multicolumn{4}{|c|}{ i pCt. } \\
\hline & & 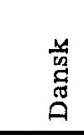 & 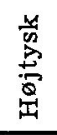 & 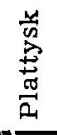 & 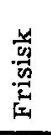 & 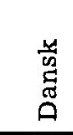 & 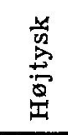 & 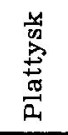 & 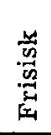 \\
\hline Selk & 181 & 79 & 22 & 79 & 1 & 43,6 & 12,2 & 43,6 & 0,6 \\
\hline 1946 & 185 & 61 & 37 & 86 & 1 & $\mathbf{3 2 , 9}$ & 20,0 & 46,5 & 0,6 \\
\hline
\end{tabular}

Tavle B. Foraldrenes Sprog med Børnene

\begin{tabular}{|c|c|c|c|c|c|c|c|c|c|}
\hline \multirow{2}{*}{ 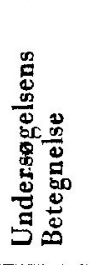 } & \multirow{2}{*}{ 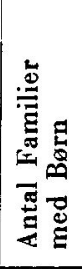 } & \multicolumn{4}{|c|}{$\begin{array}{c}\text { Antal Familien hvor } \\
\text { Egtefællerne } \\
\text { taler med Børn: }\end{array}$} & \multicolumn{4}{|c|}{ i pCt. } \\
\hline & & 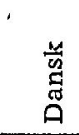 & 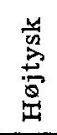 & 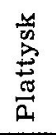 & 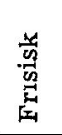 & 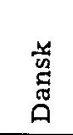 & 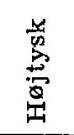 & 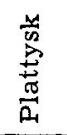 & 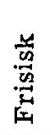 \\
\hline Selk & 110 & 25 & 30 & 55 & - & 22,7 & 27,3 & 50,0 & - \\
\hline 1946 & 100 & 8 & 39 & 53 & - & 8,0 & 39,0 & 53,0 & - \\
\hline
\end{tabular}

Tavle C Antal rensprogede Familier

\begin{tabular}{|c|c|c|c|c|c|c|c|c|c|}
\hline \multirow{2}{*}{ 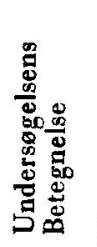 } & \multirow{2}{*}{ 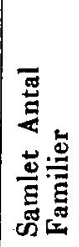 } & \multicolumn{4}{|c|}{$\begin{array}{c}\text { Antal rensprogede } \\
\text { Familier }\end{array}$} & \multicolumn{4}{|c|}{ i pCt. } \\
\hline & & 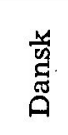 & 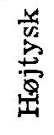 & 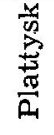 & 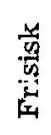 & 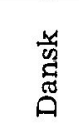 & 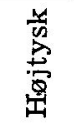 & 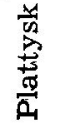 & 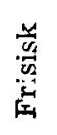 \\
\hline Selk & 181 & 47 & 16 & 60 & - & 26,0 & 8,8 & 33,1 & - \\
\hline 1916 & 185 & 27 & 21 & 53 & - & 14,6 & 11,4 & 28,7 & - \\
\hline
\end{tabular}


søgelsen, fortæller, at mens det for en Menneskealder siden var nødvendigt at kunne tale Dansk for at klare sig i Hverdagen, saa er dette ikke længere paakrævet. Dog kan alle hjemmehørende over 20-30 Aar endnu tale Dansk, og de fleste lidt større Børn forstaar Sproget.

Her som andre Steder holder Dansk sig lang bedre i Udflytterbyerne. Sprogskiftet er ikke nær saa langt fremskredet i Tætvang, Søvangager og Kalleshave som i selve Agtrup.

Det forholdsvis lille Antal højtysktalende i Agtrup viser, hvor langt den plattyske Slutfase er fremskredet.

\section{Karlum og Læksgaarde.}

Adler og H. V. Clausen opgiver for Karlum Sogn henholdsvis 66,8 og $85,6 \%$ dansktalende. Det danske Flertal paa $52,4 \%$ paa Tavle A., som Selk opgav, skulde nu være gaaet tabt, idet kun 38,5 \% af Ægtefællerne taler Dansk indbyrdes. Derimod taler endnu 51,2 \% af Ægtefællerne i de "gamle" Familier Dansk.

Tavle B. udviser kun en lille Tilbagegang, fra 34,8-25,5 $\%$. Ejendommeligt nok er den større for de „gamle“, fra 57,1$40,6 \%$.

Baade for alle Familier paa Tavle C. og for de "gamle" alene er Procenten for de dansktalende Familier godt halveret.

Som det ses, er der - hvilket ogsaa forekommer andre Steder - stor Uoverensstemmelse mellem Selks og mine Opgivelser over Antallet af "gamle“ Familier. Det maa dog ofte bero paa et Skøn, hvem der skal medregnes til de fra gammel Tid hjemmehørende. Selk regner med tre Generationer og tilsyneladende for begge Egtefællers Vedkommende. Men selv om jeg ikke er saa konsekvent paa dette Punkt og f. Eks. ikke lader det influere, hvis Omflytningen er sket indenfor samme Sogn eller mellem to Nabolandsbyer $\mathrm{i}$ den foregaaende Genera- 
Karlum.

Tavle A. Foraldrenes indbyrdes Talesprog.

\begin{tabular}{|c|c|c|c|c|c|c|c|c|c|c|c|c|c|c|}
\hline \multirow{2}{*}{ 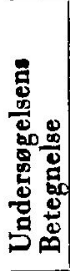 } & \multirow{2}{*}{ 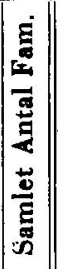 } & \multicolumn{2}{|c|}{$\begin{array}{l}\text { Antal Fam., } \\
\text { hvor Egte- } \\
\text { fallerne ind- } \\
\text { byrdes taler }\end{array}$} & \multicolumn{4}{|c|}{ i pCt. } & \multirow{2}{*}{ 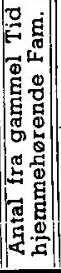 } & \multicolumn{2}{|c|}{$\begin{array}{c}\text { Antal ,gamle" } \\
\text { Familier, hvor } \\
\text { Ægtefællerne } \\
\text { indbyrdes taler }\end{array}$} & \multicolumn{4}{|c|}{ i pCt. } \\
\hline & & 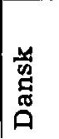 & 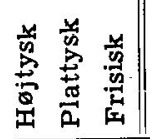 & 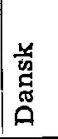 & 落 & $\begin{array}{l}\frac{y}{0} \\
\sum_{0}^{\frac{\pi}{2}} \\
\frac{\pi}{D_{1}}\end{array}$ & 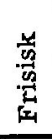 & & 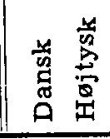 & 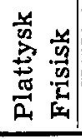 & 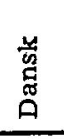 & 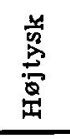 & 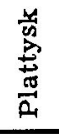 & 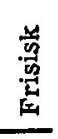 \\
\hline & 63 & 33 & $1614-$ & 52,4 & & 22,2 & - & 14 & 9 & $2-$ & 64,3 & 21,4 & 14,3 & - \\
\hline & 65 & & $2119-$ & 38,5 & 32,3 & 29,2 & - & 41 & 2112 & & 51,2 & 29,3 & 19,5 & - \\
\hline
\end{tabular}

Tavle B.

Foroeldrenes Sprog med Bornene

\begin{tabular}{|c|c|c|c|c|c|c|c|c|c|c|c|c|c|c|c|}
\hline \multirow{2}{*}{ 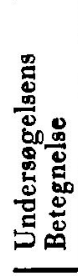 } & \multirow{2}{*}{ 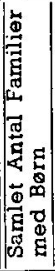 } & \multicolumn{2}{|c|}{$\begin{array}{c}\text { Antal Fam. } \\
\text { hvor Foræl- } \\
\text { drene med } \\
\text { Bernene taler }\end{array}$} & \multicolumn{4}{|c|}{ i pCt. } & \multirow{2}{*}{ 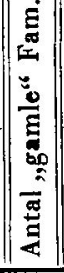 } & \multicolumn{3}{|c|}{$\begin{array}{c}\text { Deraf taler } \\
\text { med Børnene }\end{array}$} & \multicolumn{4}{|c|}{ i pCt. } \\
\hline & & 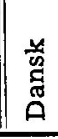 & 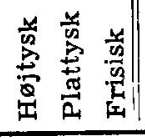 & 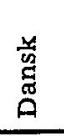 & 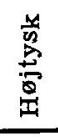 & $\frac{\substack{y \\
0}}{\sum_{0}^{\frac{N}{a}}}$ & 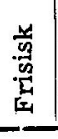 & & 艁 & 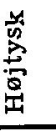 & 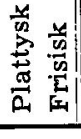 & 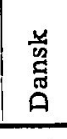 & 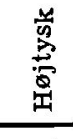 & 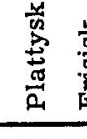 & 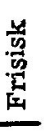 \\
\hline & 23 & 8 & $69-$ & 34 & 6.1 & 39,1 & - & 7 & 4 & 2 & $1-$ & 57,1 & 28,6 & $14,3-$ & 一 \\
\hline 4 & 51 & 13 & $2810-$ & 25,5 & 54,9 & 19,6 & - & 32 & 1316 & & $3-$ & 40,6 & 50 & $9,4-$ & \\
\hline
\end{tabular}

Tavle C.

Antal rensprogede Familier

\begin{tabular}{|c|c|c|c|c|c|c|c|c|c|c|c|c|c|c|c|}
\hline \multirow{2}{*}{ 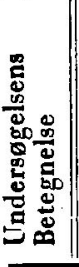 } & \multirow{2}{*}{ 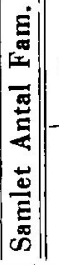 } & \multicolumn{2}{|c|}{$\begin{array}{c}\text { Antal } \\
\text { rensprogede } \\
\text { Familier }\end{array}$} & \multicolumn{4}{|c|}{ i pCt. } & \multirow{2}{*}{ 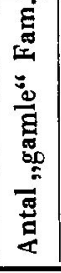 } & \multicolumn{3}{|c|}{$\begin{array}{c}\text { Antal } \\
\text { rensprogede } \\
\text { "gamle }{ }^{\circ} \text { Fam. }\end{array}$} & \multicolumn{4}{|c|}{ i pCt. } \\
\hline & & 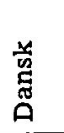 & 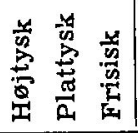 & 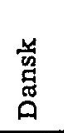 & 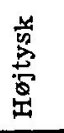 & 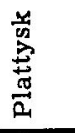 & 莺 & & 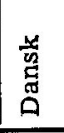 & 营 & 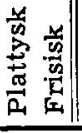 & 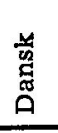 & $\frac{\substack{4 \\
0}}{2}$ & 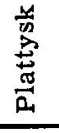 & 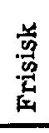 \\
\hline & 63 & & 1414 & 4,4 & 22,2 & 22,2 & 一 & 14 & 9 & 3 & $2-$ & 64,3 & 21,4 & 14,3 & 一 \\
\hline 4 & 65 & 14 & $107-$ & 21,6 & 15,4 & 10,8 & - & 41 & 13 & 4 & $2-$ & 31,7 & 9,8 & 4,9 & - \\
\hline
\end{tabular}

tion, eller hvis Hustruen er tilflyttet, saa har dette ganske givet ikke haft nogen Indflydelse paa Billedet af den normale Udvikling.

Mens i Sognets anden Landsby, Tinningsted, Plattysk er langt overvejende, saa fordeler Fremgangen for Tysk i Karlum 
og Læksgaarde sig ret jæunt paa Plattysk og Højtysk. For Tavle B er der endog Tilbagegang for Plattysk, men her er Fejlvurderinger paa begge Sider tænkelige, men det kunde dog se ud, som. om Sprogskiftet - trods den danske Tilbagegang - ikke er kommet længere ind i den plattyske Fase i de sidste 10-15 Aar.

Karlum hører til de udsatte Egne, men den samlede danske Tilbagegang er dog ikke tilnærmelsesvis saa stor som i Agtrup og i Medelby Sogn.

\section{Brarup.}

Brarup, Hovedbyen i Sognet af samme Navn, er den By, hvor der paavises den mindste danske Tilbagegang, og det er den, der blandt de undersøgte Steder har den højeste danske Procent for alle tre Tavlers Vedkommende.

H. V. Clausen opgav Sognet til at være $100 \%$ dansktalende og Selk satte, ligeledes for hele Sognet, Procenten af Ægtepar, der talte Dansk indbyrdes, til 63,4.

Paa Tavle A er den danske Tilbagegang kun fra 68,3 til 67,3. For de gamle er den lidt større, men Tallene siger med al Tydelighed, at Dansk er Landsbyens Sprog.

Selv om Nedgangen paa Tavle B. er meget større, saa er Resultatet dog slet ikke at sammenligne med de foregaaende. Og det er givet, at alle hjemmehørende Børn kan tale Dansk. En nordjydsk Landmand, der nu bor paa Tønderegnen, spurgte $\mathrm{i}$ Midten af Trediverne en Brarup Dreng om Vej paa Tysk. Han modtog Svaret: „Du kan godt tale Dansk. Jeg taler vist bedre Dansk, end du taler Tysk".

Ogsaa de rensprogede dansktalende har holdt Stillingen smukt. Særlig blandt de "gamle" er Nedgangen forholdsvis meget lille.

Fra de to andre Lokaliteter i Sognet, Holm og Uphusum, er 


\section{Brarup}

Tavle A. Foreldrenes indbyrdes Sprog

\begin{tabular}{|c|c|c|c|c|c|c|c|c|c|c|c|c|c|c|}
\hline \multirow{2}{*}{ 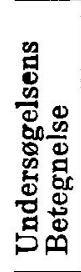 } & \multirow{2}{*}{ 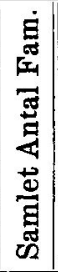 } & \multirow{2}{*}{ 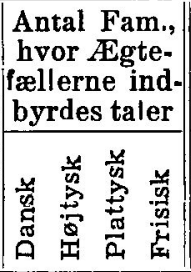 } & \multicolumn{4}{|c|}{ i pCt. } & \multirow{2}{*}{ 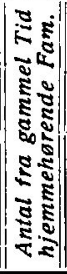 } & \multicolumn{3}{|c|}{$\begin{array}{c}\text { Antal ,gamie. } \\
\text { Fam., hvor AEgte- } \\
\text { fallesne ind- } \\
\text { byrdes taler }\end{array}$} & \multicolumn{4}{|c|}{ i pCt. } \\
\hline & & & $\frac{x}{a}$ & 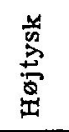 & 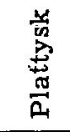 & 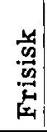 & & 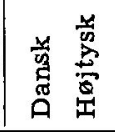 & 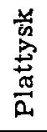 & $\frac{4}{9}$ & 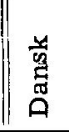 & 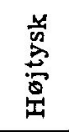 & 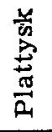 & 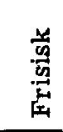 \\
\hline & 01 & $69 \quad 17 \quad 15-$ & & 16,8 & 17,0 & - & 18 & 134 & & & 72,2 & 22,2 & & \\
\hline & 104 & $70295-$ & & 27,9 & 4,8 & - & 95 & 6526 & & - & 68,4 & 27,4 & & \\
\hline
\end{tabular}

Tavle B.

Foraldrenes Sprog med Børnene

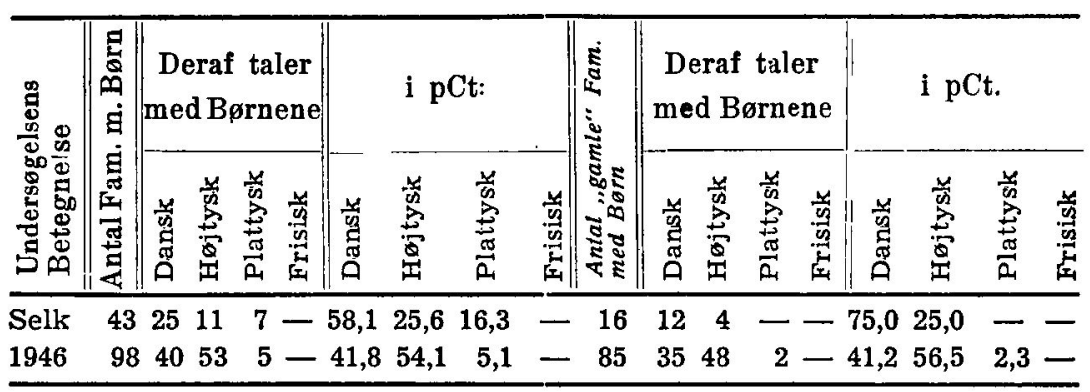

Tavle C.

Antal rensprogede Familier

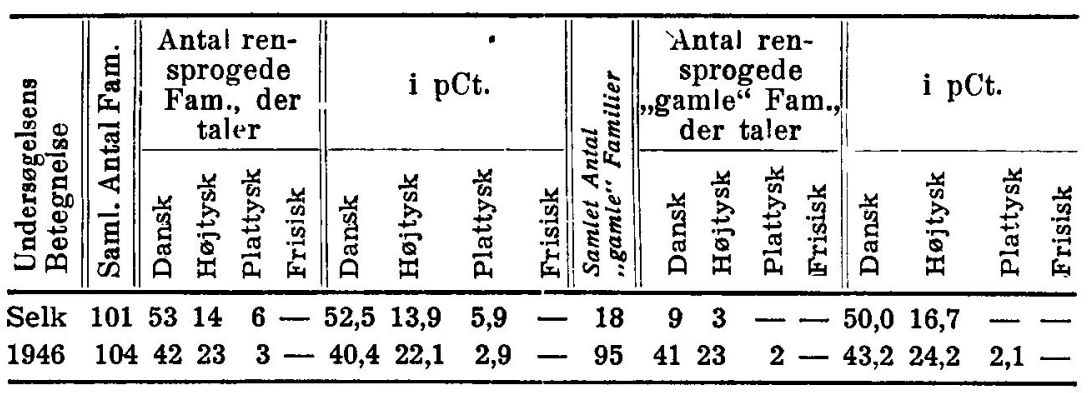

der ikke medtaget Materiale, men saadant vilde sikkert ikke forrykke Resultatet væsentligt.

Desværre savnes en Opgørelse fra Brarups Nabosogn Humtrup. Det havde i Selks Statistik den højeste Plads blandt de 
dansktalende Sogne, 72,1 \% af \#gtefællerne opgaves at tale Dansk indbyrdes. Men ud fra de Oplysninger, jeg har modtaget, er det mit bestemte Indtryk, at Dansk har holdt sig her lige saa godt som i Brarup.

Fra Sønder Løgum Sogn har jeg kun en Oversigt fra den lille Landsby Ellehøj og endda kun for Tavle A. Den viser, at af 36 Familier taler 24 Dansk, 9 Højtysk, 2 Plattysk og 1 Frisisk. Procenterne er henholdsvis $66,7,25,5,5$ og 2,8. Selk havde $78,3 \%$ dansktalende og $21,7 \%$ højtysktalende, men ingen plattysk- eller frisisktalende.

Naar hele Sognet efter Selks Opgivelser kun havde 55,3\% dansktalende blandt Forældrene indbyrdes og $22 \%$, der talte Dansk med Børnene, saa skyldes det $\mathrm{i}$ første Række den ret store Jernbanestation, Toldstationen og de mange Tjeneste- og Embedsmænd. Ogsaa for Sdr. Løgum gælder det, at det danske Sprog har holdt sig langt bedre, end Tal kan paavise.

\section{Avntoft Sogn.}

Avntoft Sogn har tidligere baade sprogligt og nationalt hørt til det frisiske Omraade, men det er i Tiden fra ca. 1500 blevet helt fordansket, og de frisisktalende, som nu findes, er tilvandrede eller Efterkommere af tilvandrede.

Undersøgelsen er for Rosenkrans foretaget af Lærer Fr. Thomsen, Nykirke danske Skole, og for Avntoft af Lærerinde Frøken Anna Schrøder, Avntoft danske Skole.

H. V. Clausen har betegnet Sognet som $97 \%$ dansktalende, og efter Selks Opgivelser indtog det Pladsen som Nr. 3 blandt de Sogne, hvor Dansk var i Overtal blandt Ægtefællerne indbyrdes, idet $66,4 \%$ af disse talte Dansk. Det kunde se ud til, at Sognet har holdt Positionen efter Ladelund, men at det er sakket agterud for Brarup.

Efter Tavle A. er Dansk næsten ikke gaaet tilbage i Rosenkrans, mens det i selve Avntoft er gaaet ned fra 65,9 til 54,4\%. 
Christian Stenz.

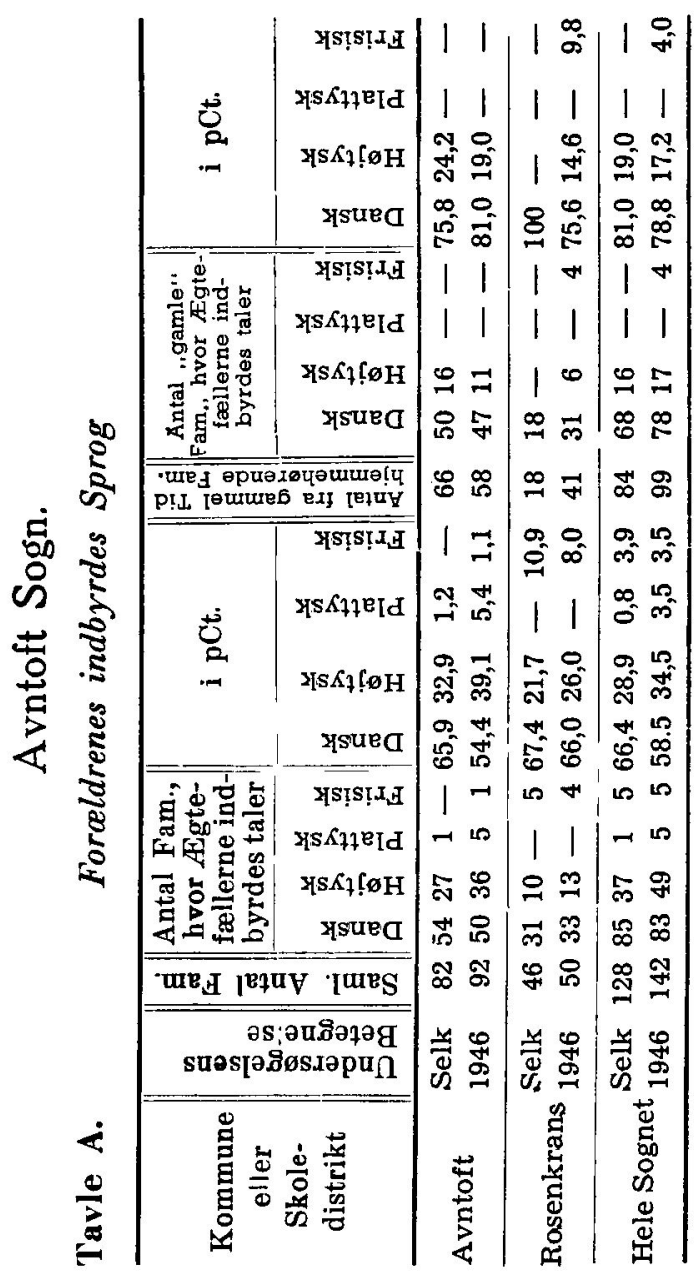

For de "gamles" Vedkommende er det omvendt, Rosenkrans en Nedgang fra $100-75,6 \%$, mens Avntoft har en Fremgang fra 75,8 til $81 \%$. Man maa her lægge Mærke til, at Antallet af "gamle“ i Rosenkrans er steget stærkt og i Avntoft er gaaet noget tilbage.

Efter Tavle B. er der en bemærkelsesværdig Forskel paa Udviklingen $\mathrm{i}$ de to Landsbyer. Mens det danske Talesprog med Børn i Rosenkrans er sunket fra 30,8 til 13,6 \%, er det i 


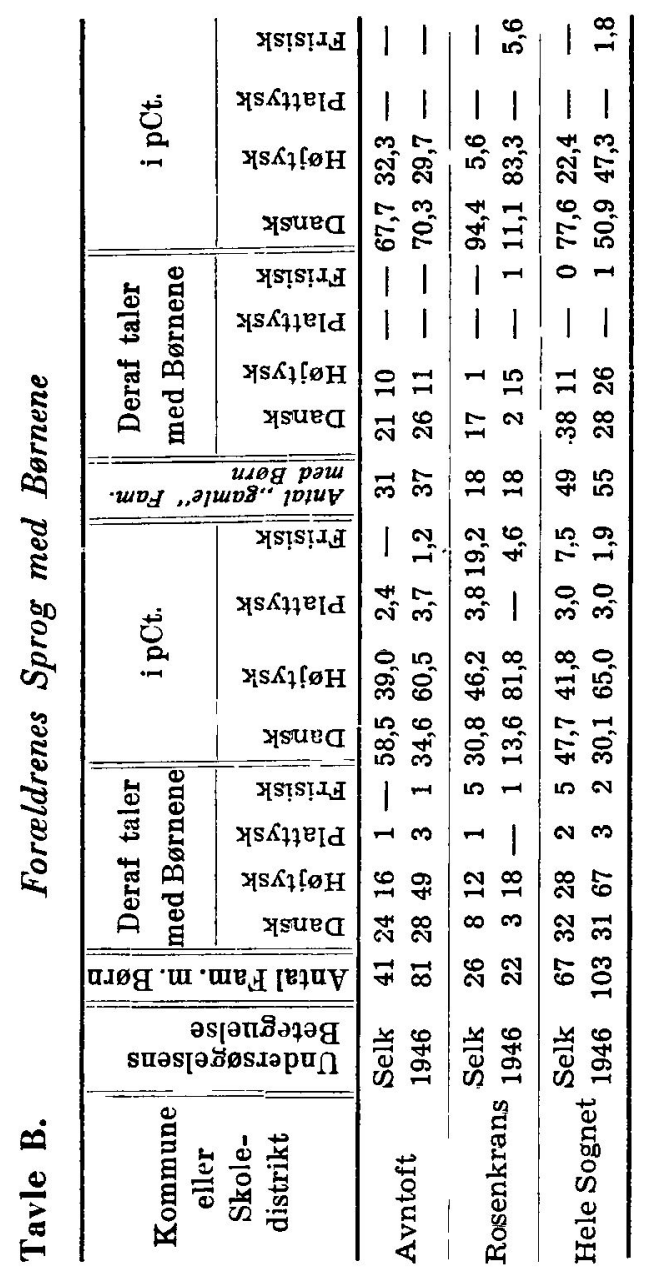

Avntoft kun sunket fra 58,5 til 34,6\%. For de "gamle“ i Avntoft er der Fremgang, men i Rosenkrans har 15 af 18 "gamle“ Familier forladt Brugen af Dansk med Børnene, omtrent en Decimering. I Gennemsnit for hele Sognet er Tilbagegangen ikke saa bemærkelsesværdig.

Paa Tavle $\mathrm{C}$ fremtræder Forskellen paa Tilbagegangen for Dansk i de to Byer endnu grellere. I Rosenkrans er de ren- 


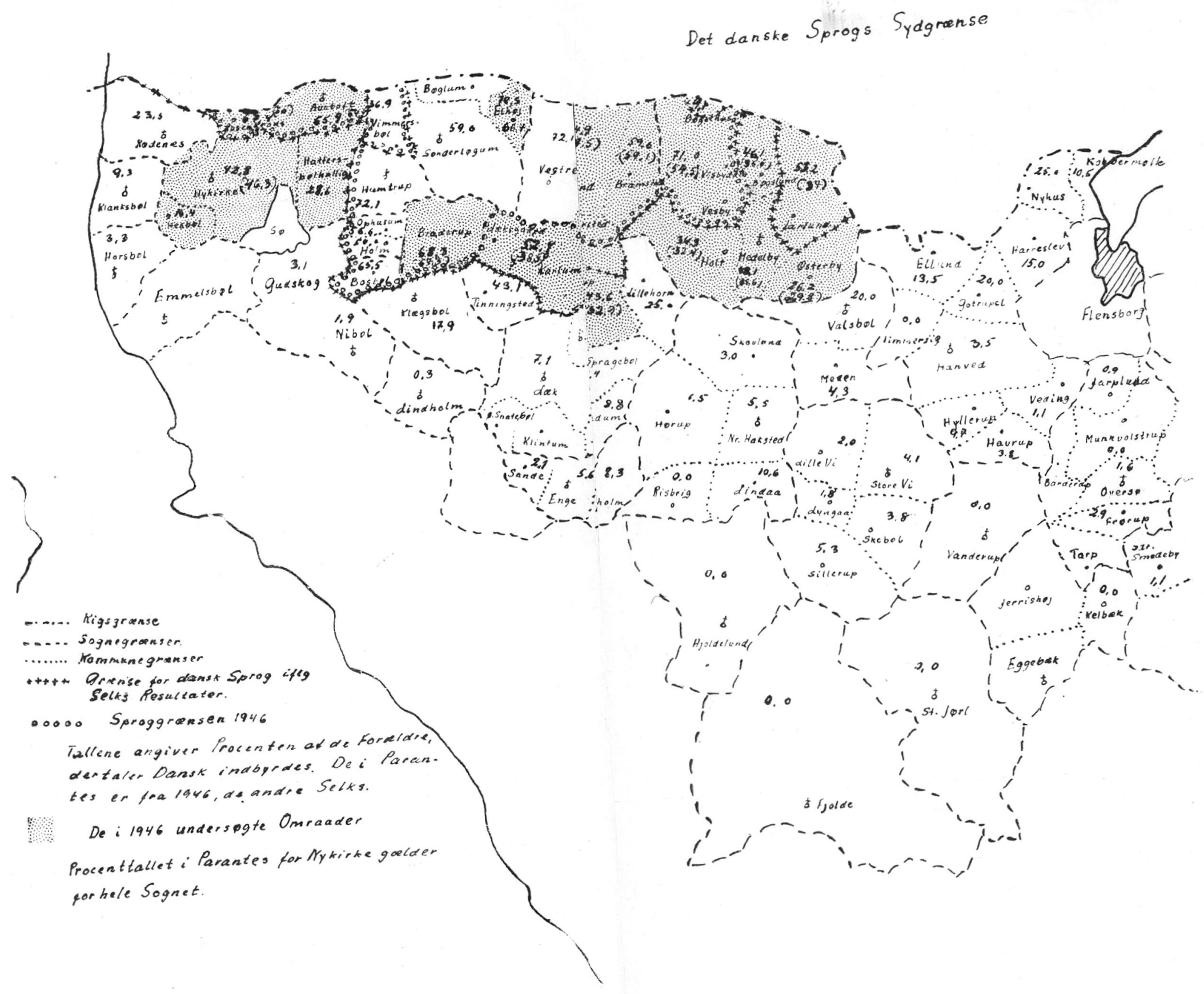




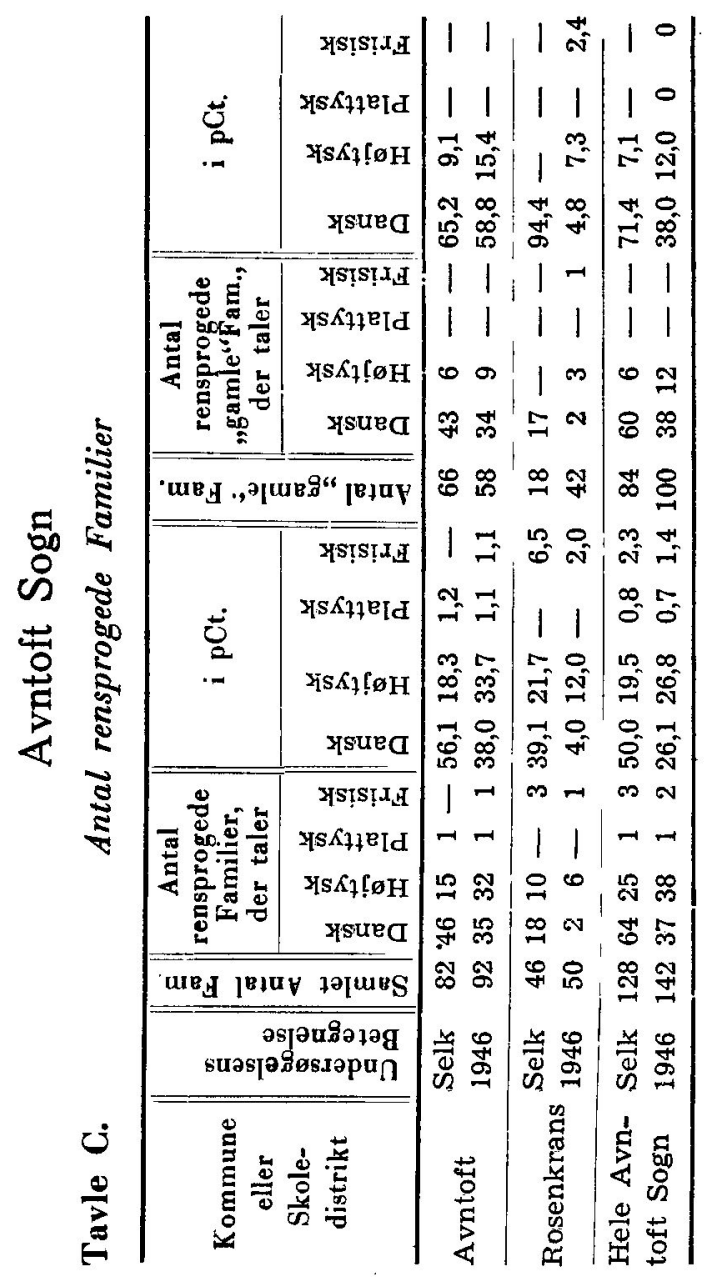

sproget dansktalende faktisk forsvundne - man lægger navnlig Mærke til de „gamles“ Nedgang fra 94,4-4,8\%, den største Nedgang, der har kunnet noteres noget Sted - mens Nedgangen i Avntoft er ubetydelig, hvilket igen medfører, at Tilbagegangen for hele Sognet ser forholdsvis normal ud.

Plattysk er saa godt som ikke repræsenteret paa Tavlerne, hvorfor Sognet maa anses for endnu at være paa første T'rin i 
Sprogskiftet. Alligevel oplyser Lærer Thomsen, at 13 af 17 Børn i den danske Skole i Rosenkrans, (der er en Underafdeling af Avntoft danske Skole) enten kan tale eller forstaa Plattysk, igen et Vidnesbyrd om Tallenes Utilstrækkelighed til Anskueliggørelse af Sprogprocessen. I denne Forbindelse har andre af Lærer Thomsens Kommentarer stor Interesse:

Efter at have omtalt Vanskelighederne ved at rubricere F'amilierne rigtigt - der er f. Eks. ofte blandt Hjemmelsmændene stor Diskussion om visse Familiers Talesprog, en Bekræftelse af mine egne Erfaringer - fortæller Thomsen om enkelte Familier:

„Fru A. A.: talte først Dansk med sin lille Pige. Da den Tid nærmede sig, at hun skulde i Skole, skiftede Sproget til Højtysk. Siden Pigen er kommet i dansk Skole, taler Moderen Dansk til hende og faar Svar dels paa Dansk dels paa Højtysk.“

„B. B.: Dansk til de to ældste og Højtysk til det yngste Barn. Stillingen nu: B. taler Dansk til begge Pigerne,.... den ældste svarer paa Dansk, den yngste oftest paa Tysk. Fru B. taler Dansk med Manden og den ældste Datter, Tysk med den yngste Datter."

„C. C.: Taler Tysk til sine dansktalende Forældre, Tysk til sin Husbestyrerinde, Dansk til de fleste af sine Naboer."

„Brødrene D.: Dansk, naar de er ædru, Tysk efter et tilbørligt Antal Grogger."*)

„Paa Legepladsen i Rosenkrans taltes 1920 kun Dansk, Foraar 1946 kun Tysk."

\section{Nykirke Sogn.}

Nykirke Sogn blev af Selk henregnet blandt de Sogne, hvor Dansk var i Mindretal eller truet. Det er medtaget i denne Undersøgelse, fordi den sydlige Del hører til det frisisktalende Omraade og der saaledes skulde være Mulighed for at

*) Det modsatte er vist almindeligere. (Forf.) 
faa et lille - men ogsaa kun et lille - Indtryk af det frisiske Sprogs Stilling i Dag.

Adler opgav for den nordlige Del af Sognet $64,4 \%$ dansktalende og 13,8 \% frisisktalende og for den sydlige Del $21 \%$ dansktalende og 64,8 \% frisisktalende. For hele Sognet giver det $40,6 \%$ dansk- og 41,7\% frisisktalende.

H. V. Clausen opgiver de tilsvarende Tal for de dansktalende til 68,26 og $44,8 \%$.

Denne Undersøgelse, der ogsaa er foretaget af $\mathrm{Fr}$. Thomsen, tager hele Sognet under eet, hvọrved man ikke kan drage Slutninger alene for den sydlige Del af Hesbøl og Hattersbølhallig. Da Selk desuden ikke har Statistik over de "gamle" Familier undtagen for selve Nykirke (bortset fra Tavle D., som jeg ikke medtager), og man saaledes ikke kan sammenligne Resultaterne, har jeg udeladt Oversigt over disse paa Skemaerne.

Tallene i Tavle A. giver Anledning til Forundring. Nykirke Sogn hører til det Omraade, hvor Dansk er trængt ind og har bredt sig paa Bekostning af Frisisk - men ikke tilnærmelsesvis i en saadan Udstrækning som i Avntoft. Selv om man baade for Selks og Thomsens Vedkommende kan henvise til Fejlmarginen, saa viser Tallene dog tydeligt, at Dansk staar langt stærkere, end man hidtil havde troet, ja, at det endog har en gunstigere Stilling, end H. V. Clausen opgiver for $1892(44,8 \%$ mod nu 46,3 - Selk har $36 \%$ ). Det kunde være fristende at forklare det ved en Teori om, at Sprogskiftet her i Stedet for at foregaa fra Dansk til Tysk foregaar fra Frisisk over Dansk til Tysk, men denne Mulighed lades straks ude af Betragtning, naar man ser, at Frisisk har holdt sig udmærket, der er kun en Tilbagegang fra $31,1-30,8 \%$, altsaa praktisk talt status quo.

Tavle B. borttager ikke Indtrykket af Tavle A. Der er en ubetydelig dansk Tilbagegang, men en frisisk Fremgang. Man bemærker Tilbagegangen baade i Familiernes Antal og i Antallet af Familier med Børn. Selv om der her kun er med- 


\section{Nykirke Sogn}

Tavle A. Forceldrenes indbyrdes Sprog

\begin{tabular}{|c|c|c|c|c|c|c|c|c|c|}
\hline \multirow{2}{*}{ 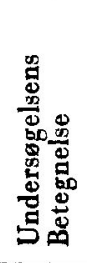 } & \multirow{2}{*}{ 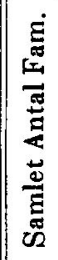 } & \multicolumn{4}{|c|}{$\begin{array}{c}\text { Antal Familier, hvor } \\
\text { Egtefællerne indbyrdes } \\
\text { taler }\end{array}$} & \multicolumn{4}{|c|}{ i pCt. } \\
\hline & & $\begin{array}{l}\text { M. } \\
\text { ⿹\zh26ّ } \\
\text { ద๊ }\end{array}$ & $\frac{\substack{4 \\
2}}{2}$ & 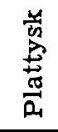 & 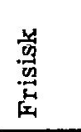 & 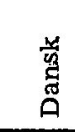 & 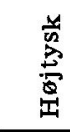 & 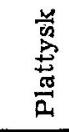 & 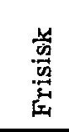 \\
\hline Selk & 228 & 82 & 47 & 28 & 71 & 36,0 & 20,6 & 12,3 & 31,1 \\
\hline 1946 & 205 & 95 & .25 & 22 & 63 & 46,3 & 12,2 & 10,5 & 30,8 \\
\hline
\end{tabular}

Tavle B. Foräldrenes Sprog med Bornene

\begin{tabular}{|c|c|c|c|c|c|c|c|c|c|}
\hline \multirow{2}{*}{ 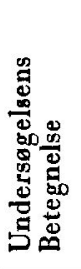 } & \multirow{2}{*}{ 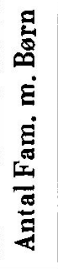 } & \multicolumn{4}{|c|}{ Deraf taler med Børnene } & \multicolumn{4}{|c|}{ i pCt. } \\
\hline & & 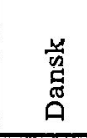 & 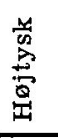 & 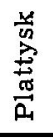 & 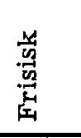 & 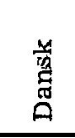 & 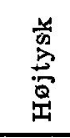 & 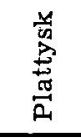 & 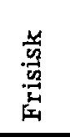 \\
\hline Selk & 162 & 39 & 56 & 18 & 49 & 24,1 & 34,7 & 11,1 & 30,2 \\
\hline 1946 & 102 & 23 & 30 & 16 & 33 & 22.4 & 29,5 & 15,7 & 32,4 \\
\hline
\end{tabular}

Tavle C. Antal rensprogede Familier

\begin{tabular}{|c|c|c|c|c|c|c|c|c|c|}
\hline \multirow{2}{*}{ 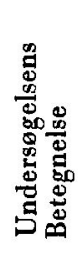 } & \multirow{2}{*}{ 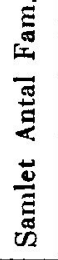 } & \multicolumn{3}{|c|}{ Antal rensprogede } & Fam. & \multicolumn{4}{|c|}{ i pCt. } \\
\hline & & 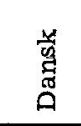 & 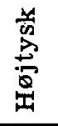 & 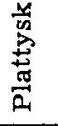 & 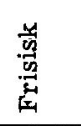 & 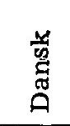 & 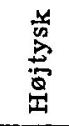 & 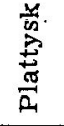 & 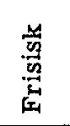 \\
\hline Selk & 228 & 43 & 46 & 22 & 62 & 18.9 & 20,2 & 9,6 & 27,2 \\
\hline 1946 & 205 & 59 & 16 & 16 & 48 & 28,8 & 7,8 & 7,8 & 23,4 \\
\hline
\end{tabular}


regnet Børn til en vis Alder, saa skulde dette ikke give hverken Dansk eller Frisisk en gunstigere Stilling.

Paa Tavle C. noterer man en stor dansk Fremgang og en lille frisisk Tilbagegang.

Antallet af de Forældre, der taler Plattysk med Børnene, er gaaet lidt frem, fra $11,1-15,7 \%$. Men ellers viser Tavlerne overalt for Nykirke Sogn en Tilbagegang for det tyske Sprog. Lærer Thomsen oplyser, at alle Børn kan forstaa og tale Plattysk - hvad ogsaa. Selk meddeler - mens efter en anden Opgørelse, som behandles senere, kun $11,6 \%$ af Skolebørnene kan tale og forstaa Dansk. Dette kunde synes at være i skærende Modstrid med Opgivelserne i Tavle $B$, der siger, at 22,4 \%. af Forældrene taler Dansk med Børnene. Men naar man erfarer, at $50 \%$ af Børnene i den danske Skole mod kun $3,3 \%$ i den tyske Skole opgives at kunne tale og forstaa Dansk, bliver det klart, at Paalideligheden af den sidste er mere end tvivlsom. Undersøgelsen i den danske Skole er foretaget paa Grundlag af Tilstanden før dennes Oprettelse, og at tænke sig dens Elever langt overvejende rekrutteret fra dansktalende Hjem har intet med Virkeligheden at gøre. Men den store Forskel mellem de opgivne Antal dansktalende Børn i de to Skoleafdelinger har maaske sin naturlige Forklaring:

Det er et velkendt Fænomen, at mange Sydslesvigere ikke erkender, at de taler eller i det mindste kan tale Dansk. I bedste Fald hævder de, at det ikke er rigtig Dansk, de taler, det er „Kartøffeldansk“ eller „Platdansk“. Man kan meget let tænke sig, at mange Born i Nykirke tyske Skole ikke selv er klar over, at de kan tale Dansk. I et Sogn, hvor Dansk, Frisisk, Plattysk og Højtysk bruges i Flæng, kniber det, navnlig for Børn, som ikke tænker over det, at erhverve sig en klar Erkendelse over disse Forhold. Og det viser igen Utilstrækkeligheden i at lade de undersøgte Personers eget Vidneudsagn være afgørende ved Vurderingen, specielt naar det drejer sig om Børn.

Men selv om man nu for Nykirke Sogn i særlig Grad har 
belastet Fejlmarginen, saa er der ingen Tvivl om, at Sognet indtager en ganske enestaaende Stilling i Sprogkampen. Dette er ikke nogen ny Iagttagelse. Dr. Bock har gjort opmærksom paa det*) og antydet, at Grunden kan skyldes Nykirkes isolerede eller beskyttede Stilling mellem dansk- og frisisktalende Sogne.

Der foreligger ogsaa en Opgørelse over det frisiske Sprogs Stilling blandt Skolebørnene. Af 146 Børn kan 59 tale og forstaa Frisisk - 40,5 \% - 19 kan forstaa Frisisk uden at kunne tale det, mens 66 hverken kan tale eller forstaa Sproget. (Undersøgelsen omfatter baade den danske og den tyske Skole, og Forholdene mellem dem er omtrent det samme). Altsaa kan over Halvdelen af Skolebørnene forstaa Frisisk. Efter en officiel Statistik havde i 1932 24,8 \% af Skolebørnene Frisisk som Talesprog. Naar man betænker, at Hesbøl Skoledistrikt, der i Særdeleshed er frisisktalende, ikke er medregnet her, saa afgiver Undersøgelsen et Vidnesbyrd om, at det frisiske Sprog har hævdet sig smukt i Konkurrencen.

Ogsaa fra Nykirke bringer Fr. Thomsen Kommentarer:

„A. A. taler Højtysk og Dansk (Højtysk hjemme), men naar han skælder ud, hvad ofte sker, er det mest paa Plattysk".

„Fru B. B. taler Dansk, men vil helst tale Højtysk med Læreren (ogsaa den danske Lærer)“.

„C. C. har talt Højtysk med Børnene og Dansk med Konen. Taler nu Dansk med den yngste Pige, men skælder Konen ud paa Højtysk".

„Fru D. D. taler Dansk, men naar hun vil være morsom for det meste Plattysk".

„Det gælder næsten alle, at det højtidelige let bliver Højtysk ......".

Thomsens Oplysninger er ikke specielt typiske for Rosenkrans og Nykirke. Lignende Træk kan fremdrages fra hver

*) Karl N. Bock: Mellemslesvigs Sprogforhold i Fr. v. Jessen: Haandbog i det slesvigske Spørgsmaals Historie. 
eneste Landsby i det dansktalende Omraade i Mellemslesvig, men de kan især bidrage til at vise Vanskelighederne ved at foretage en sproglig Undersøgelse.

\section{Sammenfattende Oversigt.}

Da Medelby Sogn indtager en Særstilling, fordi det i særlig Grad bidrager til at nedsætte Gennemsnitsprocenten af de dansktalende, har jeg givet dette Sogn en særlig Plads i Sammenstillingen.

Ialt er 1247 Familiers sproglige Forhold gjort til Genstand for Undersøgelse. Selk havde i det samme Omraade $1168 \mathrm{Fa}-$ milier. Det Flertal, som de dansktalende Forældre udgjorde, ses at være gaaet tabt, men undtager man Medelby Sogn, hvor kun Vesby Kommune har et dansktalende Flertal, taler endnu $50,5 \%$ af $Æ g$ tefællerne Dansk indbyrdes. For de "gamle“ er Tilbagegangen meget større, men uden for Medelby Sogn dog ikke bemærkelsesværdig.

I Tavle B. viser Medelby Sogn ogsaa den største Tilbagegang, men alligevel er den samlede Tilbagegang for hele Omraadet væsentligt større end i Tavle A., navnlig for de "gamle" Familier. Tallet paa dem, der taler Dansk med Børn, er dalet fra 33,7 til 22,6, med ca. en Trediedel, og for de "gamle" fra $\mathbf{5 2 , 2}$ til $32,9 \%$, altsaa med c. to Femtedele. For de sidstnævntes Vedkommende er Nedgangen omtrent lige stor i Medelby Sogn og i det øvrige undersøgte Omraade.

Paa Tavle C. er Procenten af rensprogede danske Familier ikke meget reduceret, og Forholdet er omtrent det samme i begge Omraader. 22,1\% skulde i Dag være rensproget danske mod før 29,5\%, for de "gamle" $29,3 \bmod$ før $37,6 \%$, altsaa omtrent det samme Forhold.

Alle tre Tavler viser, at der saa godt som ingen Fremgang er for det plattyske Sprog. Det tyder paa, at Kampen endnu i 


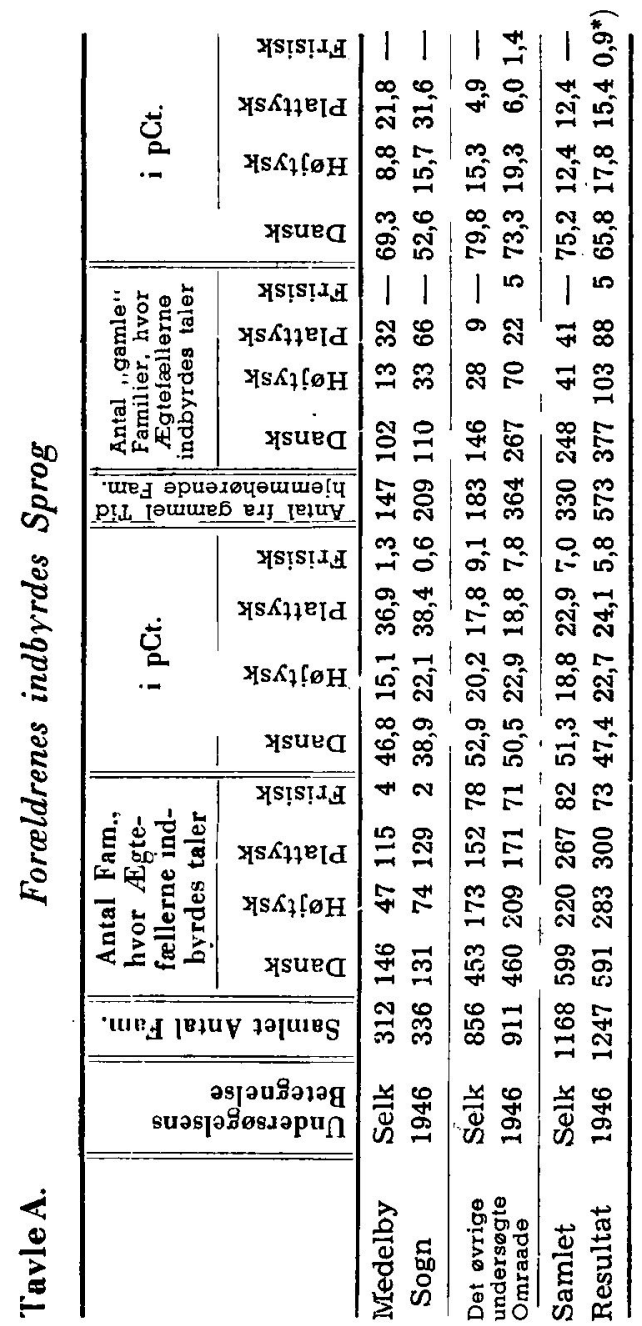

første Række staar mellem Højtysk og Dansk, og at det trækker i Langdrag med den plattyske Slutfase.

Om det frisiske Sprog kan der ikke dannes Slutninger ud fra de her opgivne Tal, - som med Undtagelse af Nykirke Sogn, hvor Frisisk jo hæydede Positionen - kun omhandlede tilvandrede. 


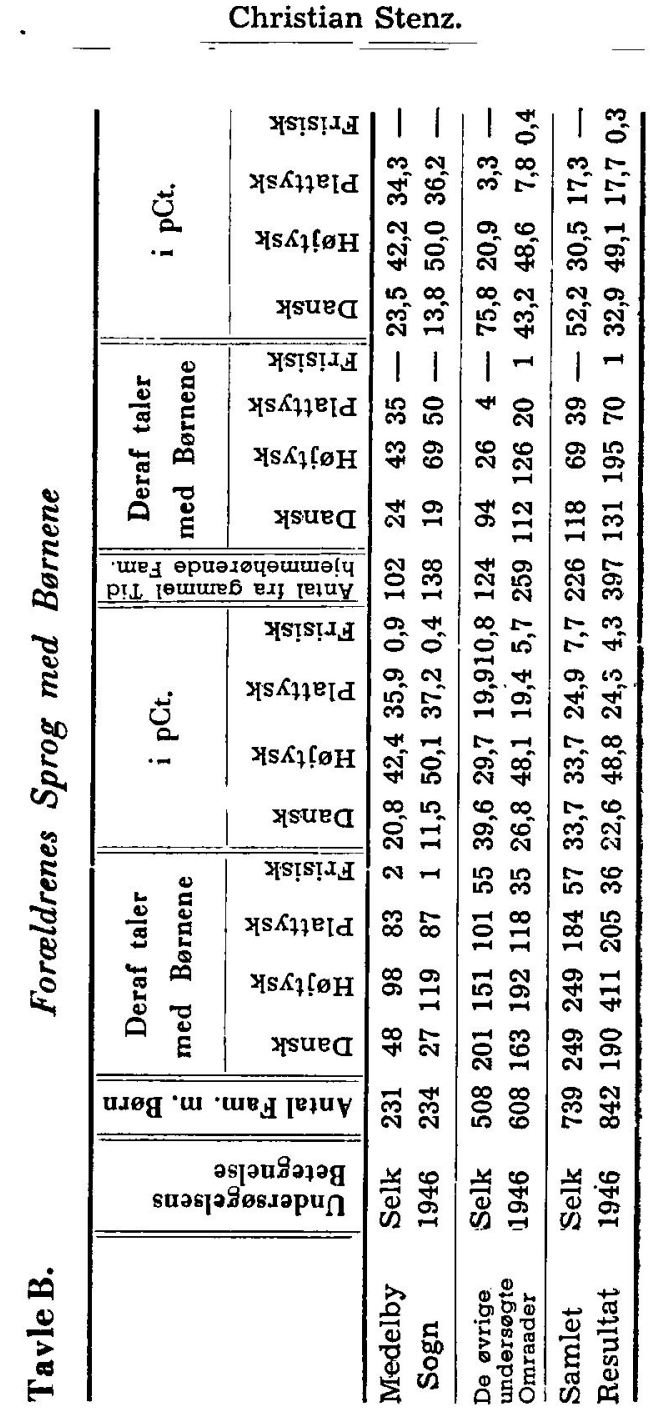

Ud fra Tallene kan man heller ikke beregne, hvor mange dansktalende der i Dag findes i Sydslesvig. Karl N. Bock anslog i 1938 det samlede Antal dansk- og tvesprogede til at udgøre ca. 7000 Personer. Ifølge Selk talte i det her behandlede Omraade i 599 Familier Ægtefællerne Dansk indbyrdes. Dette Tal er kun dalet til 591, men Tallet paa Familier, i hvilke der tales Dansk 


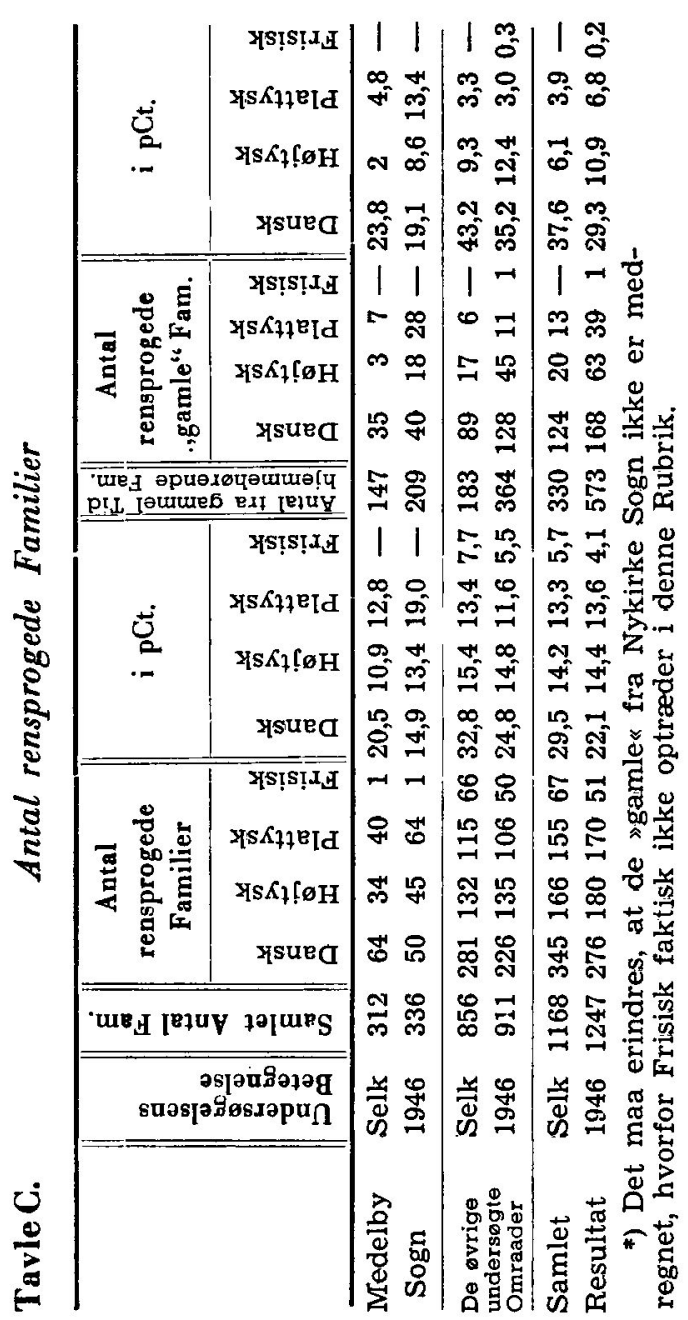

med Børn, er faldet fra 249 til 190. Men Børnene i disse Hjem kommer næsten alle til at tale Dansk, naar de naar en vis Alder, saa det er et Spørgsmaal, om Antallet af dansktalende Personer overhovedet er blevet formindsket. Det kan ikke udreg. nes, hvor mange der kan tale Dansk, men det er ikke utænkeligt, at man her vil opnaa et flere Gange saa stort Antal. 


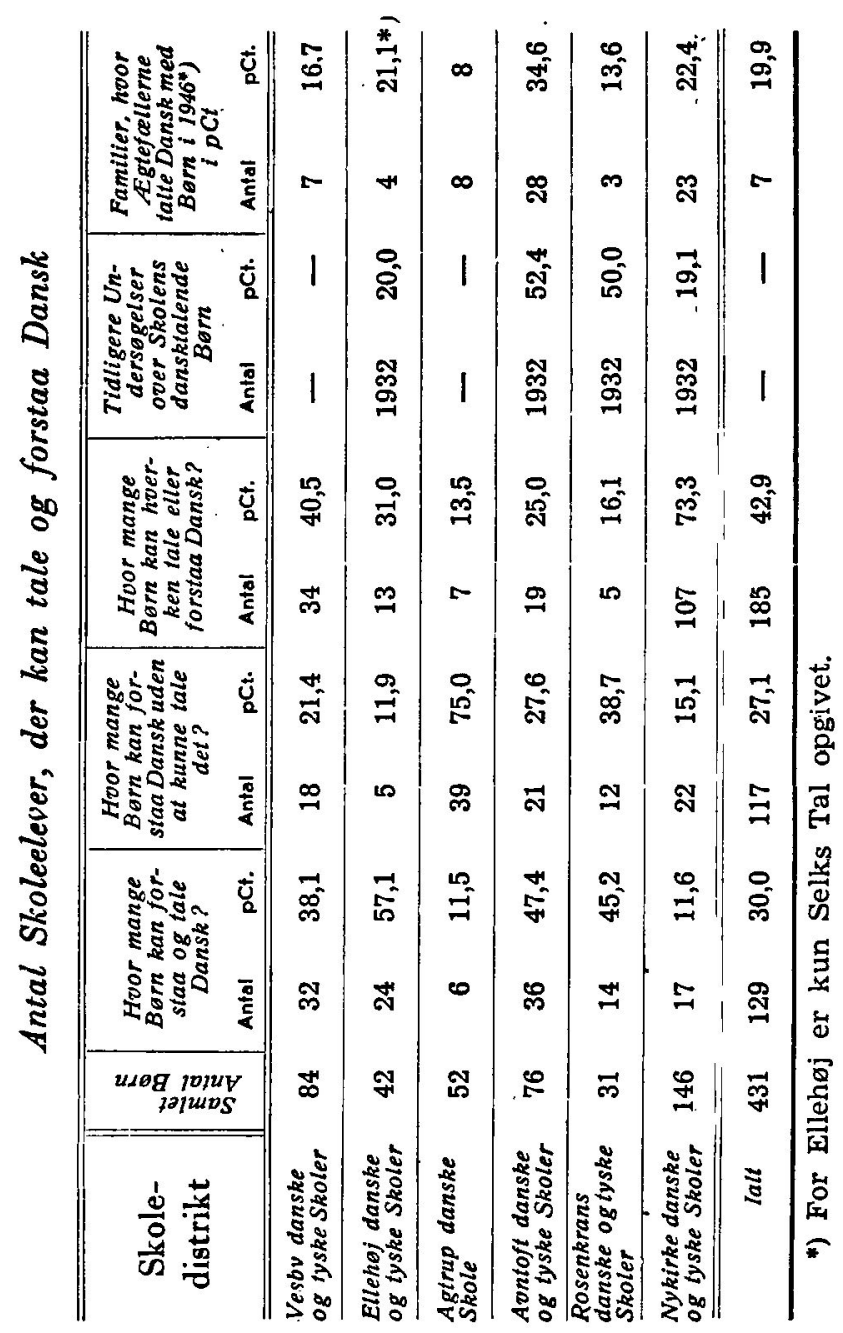

I denne Forbindelse kan det have sin Interesse at betragte nogle Tal fra enkelte Skoler med Angivelse af, hvor mange Elever der kan tale og forstaa Dansk.

Med Undtagelse af Nykirke, hvis Forhold er omtalt andetsteds (Side $179 \mathrm{ff}$.), er Antallet af Børn, der kan tale Dansk, betydeligt større, end man vilde vente det ifølge Tavle $B$. Tilsammen kan 57,1\% af Børnene i de nævnte Skoler tale eller forstaa 
Dansk: Der gælder det samme for de andre Skoledistrikter som for Nykirke, at de dansktalendes Antal i de danske Skoler er meget større end i de tyske, men her maa det for det første betænkes, at de tilvandredes Born naturligvis gaar $\mathbf{i}$ de sidstnæunte, og for det andet er det min Overbevisning, at Tallene fra disse er sat alt for lavt.

\section{Slutning.}

Det kan med nogenlunde Sikkerhed fastslaas, at det danske Sprog er gaaet lidt tilbage, hvad angaar Ægtefællernes indbyrdes Talesprog, at det er gaaet meget tilbage, hvad angaar Talesproget med Børn, og at Antallet af rensprogede dansktalende Familier er noget formindsket. Tilbagegangen er størst i den østlige Del af det undersøgte Omraade, og det danske Sprog holder sig forholdsvis langt stærkere længere mod Vest. Grænsen for det Omraade, hvor det danske Sprog er i Flertal, er trængt noget tilbage og skulde nú gaa saaledes:

Fra Statsgrænsen Vest om Bøgelhus, langs Østgrænsen af Vesby Skoledistrikt, følge Ladelund Sogns Sydgrænse (og Sdr. Løgums), langs Brarup Sogns Sydgrænse, derefter følge Humtrup Sogns Vest- og Nordgrænse, afskære Vimmersbøl af Sdr. L.øgum Sogn, følge Statsgrænsen til Avntoft Sogn, hvorefter den gaar Syd om dette Sogn og til Slut følger Statsgrænsen ud til Havet. (Der maa desuden regnes med, at Bodsbøl af Klægsbøl Sogn, der iflg. Selk havde 65,6\% dansktalende paa Tavle A., stadig ligger indenfor det overvejende dansksprogede Omraade).

Der er siden 1937 kun sket den Forandring i Sproggrænsen, at Jarlund og Karlum nu skulde ligge uden for det overvejende dansktalende Omraade.

Alt i alt er Hovedresultatet ikke slet saa nedslaaende, som man kunde have ventet. Der maa regnes med en vis Konservatisme, som stædigt vægrer sig ved helt at bryde med Moders- 
maalet, og der skulde saaledes være et godt Grundlag her for det sproglige Arbejde, som udføres af danske Skoler og gennem anden Kulturvirksomhed.

Der har blandt nogle af Arbejderne i dette Kulturarbejde været Drøftelser om Arten af Sydslesvigs fremtidige Talesprog. Man diskuterede, om Børnene, efterhaanden som de blev dansktalende, vilde komme til at tale det saakaldte FlensborgDansk, et akcentpræget Rigssprog, eller om den gamle sønderjydske Dialekt vilde formaa at vinde Udbredelse. Selv under de aller gunstigste Betingelser vil der sikkert hengaa mindst en Menneskealder, inden det danske Sprog tager Førerskabet $\mathbf{i}$ Sydslesvig, og det er da indlysende, at det i første. Omgang bliver det saakaldte Rigssprog, Skriftsproget, der tales, da der kun i en meget lille Del af Sydslesvig er bevaret en dansk Dialekt. Men der er allerede nu (Februar 1947) Vidnesbyrd om, at i de danske Skoler, hvor blot enkelte Børn taler Dialekt, eller blot nogle Voksne i Byen taler en saadan, der vil ogsaa de Børn, som ira at være rent tysktalende bliver dansktalende, tale Dialekt. Det er et glædeligt Tegn, og det giver Haab om, at Omstillingen til dansk Talesprog vil gaa over Kultursproget til Dialekten, ligesom nu det tyske Sprog breder sig over Højtysk til Plattysk.

Man har saaledes Lov til at vente, at Dialekterne kan vinde frem imod Syd, i Særdeleshed kan denne Udvikling tænkes at tage Fart, naar Forbindelsen med Nordslesvig bliver genoptaget. Ved Anbringelse af Feriebørn fra Sydslesvig i Nordslesvig kunde der være Anledning til at tage dette Forhold i Betragtning.

Til Slut kun følgende:

Som tidligere omtalt kan man ikke vente at faa en fuldt udtømmende og fuldt paalidelig Redegørelse over det danske Sprogs Stilling i Mellemslesvig. Et Sprogskifte er en saa kom pliceret Proces, at det ikke alene lader sig anskueliggøre af et statistisk Materiale og af procentuale Udregninger. Men det er 
mit Haab, at der gennem den her foreliggende Undersøgelse naar Hensyn tages til uundgaaelige Fejlvurderinger og Fejlslutninger, kan gives et Indtryk af Stillingen i Dag og at $i$ det mindste Tendensen i hele den sproglige Udvikling kan paavises. Er dette Tilfældet, er Hensigten fra min Side naaet.

Christian Stenz. 